\title{
8 The Muslim People of Desht-i Qipchaq in Fifteenth-Century Prussia
}

\subsection{Prolegomenon}

Late medieval Prussia, stretching across the southern Baltic coast from a small river called the Leba in the west beyond the estuary of the Memel (Nemunas) in the east, ${ }^{1}$ was a heterogeneous country, both governmentally and culturally dominated by the Teutonic Order. ${ }^{2}$ The military order arrived in the area in c. 1230 , and over the subsequent fifty years gained control of the Baltic communities between the lower Vistula and Pregel (Pregoła), ${ }^{3}$ laying the foundation for its dominion (Herrschaft) over the area, which, as the fourteenth century progressed, increasingly took on the form of territorial dominion (Landesherrschaft). ${ }^{4}$ At the same time, the Order established a specific socio-political system based both on a growing network of settlements and on the social interactions between various communities and individuals. ${ }^{5}$ Beginning with Reinhard Wenskus' study from 1975, 6 it has become increasingly clear that this sociopolitical system was not of a 'colonial nature', with one foreign ethnic group establishing predominance, as Karol Górski had previously claimed, ${ }^{7}$ but was made up of a multi-ethnic network with relatively complex and dynamic relations. Subsequent detailed studies addressing different aspects have shed additional light on this reality. ${ }^{8}$ In 2008, Jürgen Sarnowsky published a comparative depiction of the functioning of multi-ethnic societies in the fifteenth century in Prussia and on Rhodes. In the case of the Greek island, religious diversity also played a role in how multi-ethnicity was understood. ${ }^{9}$

1 Regarding the development of this term cf. Maschke 1970, 158-165.

2 Militzer 2005, 63-77, 95-111, 143-152; Sarnowsky 2007, 35-51, 72-76, 81-86, 89-98.

3 Ewald 1872-1886; Zajączkowski 1935, 5-30; Labuda 2000, 162-185, 202-210; Boockmann 1994, 93-113.

4 Wenskus 1986a; generally also: Militzer 2005, 72-77, 107-111; Sarnowsky, 2007, 42-47.

5 I recently addressed this aspect of the Teutonic Order's rule in the first section of my dissertation, see Kwiatkowski 2013.

6 Wenskus 1986b (originally published 1975).

7 Górski 1938, 55-56; Górski 1946, 13; Górski 1977, 9; the Italian edition of the study, Górski 1971, 15; and Górski 1976, 13-31; Górski 1986, 22-23, 29, 69-70, 77; Łowmiański 1989, 125-126.

8 Czaja 1995b, 9-34; Czaja 1995a, 111-123; Czaja 2000, 57-76; Czaja 1999, 111-177; Souhr 2009, 7-37; Kubon 2012, 98-118; Kwiatkowski 2009a, 170-176, 184-186; Kwiatkowski 2009b, 25-28.

9 Sarnowsky 2006/2008, 175-187. 
In the earlier Prussian studies addressed by Sarnowsky, three main ethnic groups inhabiting and colonizing late medieval Prussia were juxtaposed: a German-speaking population that came primarily from the Lower, the Middle, and the Rhine region of the Reich; ${ }^{10}$ Slavic people, primarily Pomeranian, Mazovian, and Polish; ${ }^{11}$ and indigenous Baltic people..$^{12}$ In the 1940s, Henryk Łowmiański provided an estimate of the size of each of these groups in the early fifteenth century - a Germanic population of $190,000(200,000)$, a Slavic population of 130,000 (140,000), and a Baltic population of approximately $140,000 .{ }^{13}$ Among the Baltic tribes, both native Old Prussians and Jatvingians, as well as Samogitians who came from the east, and Lithuanians, ${ }^{14}$ there were some who maintained local, tribal pagan cult practices. It has, however, proven impossible to provide an accurate estimate of their numbers.

Does this brief outline of the threefold ethnic division and twofold religious division accurately depict the reality of late medieval Prussian settlement, ethnicity, and religion? It can undoubtedly be seen as an accurate reflection of the significance of those particular ethnic groups and religious divisions in the Prussian region, but it nonetheless lacks precision. In addition to the dominant German minority, ${ }^{15}$ extant sources confirm the presence in fifteenth-century Prussia of people from other ethnic groups and religious traditions. Besides Catholic Englishmen, ${ }^{16}$ partially Christianized Baltic Kurs/Curonians, ${ }^{17}$ and Or-

10 Zajączkowski 1935, 34-35, 38; Penners 1942 (among others pp. 46-96, 138-157); Jasiński 1999, 95-110; Boockmann 1994, 118, 125, 132; Wenta 1987 (for a concrete example); Biskup 2000, 316-318; Długokęcki 2008a, 200-204.

11 See for example Zajączkowski 1935, 39, 43, 44-50 (includes references to older literature); Penners 1942, 162-166; Wenskus 1986b, 367-370; Biskup 2000, 320-322; Schumacher 1977, 72; Małłek 2003, 438-440; Długokęcki 2008a, 210-211, 217.

12 Zajączkowski 1935, 39, 43, 49 (includes references to older literature); Łowmiański 1989, 156-158; Penners 1942, 166-168; Wenskus 1986b, 355-364; Wenskus 1986c, 245-298); Biskup 2000, 322-324; Długokęcki 2008a, 205-205, 208, 211-212.

13 Łowmiański 1989, 160; Powierski 1981, 138-139; Biskup 2000, 367-368; Boockmann 1994, 111; Sarnowsky 2007, 41-42. Data provided by Boockmann 1995, 138; Sarnowsky 2006/2008, 176, claims there were about 140,000 Prussians, 103,000 German-speaking people, and 27,000 Polish-speaking inhabitants c. 1400 in the area of the old ethnic Prussia and Chełmno Land the authors made a mistake, which unfortunately leads to misunderstandings. It should be noted that all of the estimates were based on fragmentary settlement studies (for particular areas), with the results transposed to other areas, or were based on very general estimates of the overall population density across the country.

14 Mortensen 1927, 177-195; Mortensen 1933, 134-137; Zajączkowski 1935, 51-52; Wenskus 1986b, 372-374; Schumacher 1977, 72; Długokęcki 2008b, 382-383; Małłek 2003, 440; Jähnig 1999, 75-94; Vercamer 2010, 286-287.

15 Sarnowsky 2006/2008, 177.

16 Penners 1942, 51, 53, 65, 68, 73, 78, 83; Jenks 1985, 105-120.

17 Mortensen and Mortensen 1938, 144-146, 147-149, 173-175; Długokęcki 2008b, 382-383. 
thodox Ruthenians, ${ }^{18}$ there is evidence of the presence of Islamic Tatars. The Teutonic Order in Prussia, and its territorial dominion ([Landes]Herrschaft) of Prussia, is usually, and largely accurately, associated with a 'holy war' against pagans on the far edges of the then Western Christian ecumene. ${ }^{19}$ In this context, the Muslims mentioned in the title referred to in relation to Prussia might in some cases be the marauding Mongolian army, which by the second half of the thirteenth century may have occasionally reached the southern edges of Prussia. ${ }^{20}$ Alternatively, it might refer to Cuman (Qipchaq) ${ }^{21}$ and Tatar allies of the grand dukes of Lithuania and Polish kings during the wars waged against the Order in the fourteenth, fifteenth, and early sixteenth centuries (1330, 1410, 1414, 1422, 1519-1521).22 Indeed, the Mongolian Muslims, who occasionally appeared alongside Jagiellonian troops in Prussia, served a significant propaganda purpose in the Order's efforts to present itself as 'the shield of Christianity'. ${ }^{23}$ They allowed the Order to present its actions in an even more virtuous light. Not only did it stand against the Baltic pagans, the superficially converted Lithuanian Christians, the Russian schismatics, and their traitorous Polish Catholic supporters, but it also stood against the infidels - the followers of Allah - who rushed to their aid. ${ }^{24}$

18 Mortensen and Mortensen 1937, 192; Mortensen and Mortensen 1938, 110-111 and nn. 465, 470-471; Schumacher 1977, 72; Długokęcki 2008b, 381; Vercamer 2010, 286.

19 Weise 1963-1964, 426-456, 401-410; Boockmann 1975, 50-129; Kwiatkowski 2013, 96-97. 20 FTAP, 62; ChTP, 469; Töppen 1861, 148, n. 2; Maercker 1899-1900, 134; Krakowski 1956, 205, 210-212, 215-219; Wyrozumski 1982, 83, 84; Sarnowsky 1994, 257 and n. 26; Czarciński 1994, 35; Tyszkiewicz 1989, 103, 105-107, Tyszkiewicz 2008e, 32-33; Żmudzki 2000, 448, 454457.

21 On the Muslim religion of the Cumans in the fourteenth century, see Vásáry 2005; Golden 2003; Horváth 1989.

22 Regarding the 1330 campaign, see FTAP, 58; Detmar, 58; regarding the fifteenth- and early sixteenth-century wars, see Biskup 1993, 50, 58, 59, 60, 67, 74, 75, 78, 86, 91, 103, 105, 127, 274275, 280, 281, 293, 295, 297; Tyszkiewicz 1988, 86-87; Tyszkiewicz 1989, 158, 159, 183, 187-188, 190-200; Tyszkiewicz 1991, 62, 107-115; Tyszkiewicz 2008a, 142-148; Tyszkiewicz 2008b, 7187; Tyszkiewicz 2008c, 114, 118-122.

23 Boockmann 1975, 86-89, 90-101; Hoffmann 1965, 69; Sarnowsky 1998, 114; Souhr 2012.

24 From the early 1390s, but particularly following the defeat of the Crusader army in the Battle of Nicopolis (25 September 1396), the Prussian Branch of the Order was increasingly interested in acquiring land in Serbia and Transylvania (in particular, in Burzenland), to improve the Order's access to the 'Turkish frontline', responding to Poland's and Lithuania's allegations, see Joachim 1911, 3; Sarnowsky 1994, 260; Sarnowsky 1998, 114-115. In the years 1429-1432, the Order was militarily active in the area of Banat, see Joachim 1911, 10-19; Forstreuter 1936, 259-260; Hoffmann 1965, 74; Boockmann, 1975, 70-71; Sarnowsky 1994, 261; Thumser 2000, 142-143. 
The above-mentioned passing military presence of Muslims in late medieval Prussia represents only one aspect of a wider phenomenon, which also has facets unrelated to war and confrontation. The written source material, of which a significant amount from the late fourteenth century through the first three decades of the fifteenth century has been preserved, confirms the presence of people of a Muslim origin in Prussia for reasons unrelated to war. Information, although scarce, can be found in a Prussian chronicle written by a Pomesanian judicial vicar during the first quarter of the fifteenth century. ${ }^{25}$ The second type of source material that includes data relevant to this analysis are the records of Teutonic Order provenance related to the management of their dominion and to communication between officials, the latter including letters ${ }^{26}$ and various administrative books ${ }^{27}$ from the early fifteenth century.

This essay is concerned with the insufficiently examined long-term presence of a population of Muslim origin in the Prussian Land. Such issues as the reasons for and circumstances of the Muslim population's appearance, their numbers, the forms and durability of their settlements, the role they played in the political and social system of the dominion, and finally acculturation and its determinants, have all become key points of interest. An attempt will be made to place this phenomenon in the context of the multi-ethnic and bi-cultural structure of Prussian society in the Late Middle Ages.

\subsection{The circumstances of arrival and the sites of settlement}

Both the Pomesanian judicial vicar's chronicle of and the records of the socalled Marienburger Tresslerbuch ${ }^{28}$ attest to the presence of people known as Tatern and Tataren in Prussia. The first records date back to 1402. In the chronicle describing the Lithuanian and Samogitian attack on Ragnit (Neman), which

25 Posilge, 79-388. The origin of this written record is controversial; previously it was assigned to the canon, Johann von Posilge, but another hypothesis claims the work for Johann von Redden; more recently, it has been suggested that the author of this work is a certain Peter, who held the office of the chapter official, see Wenta 1990, 16-29; Wenta 2000, 237-239; Päsler 2003, 284-290; Mentzel-Reuters 2013, 93-96.

26 GStA PK, Altfindmittel, Fotokopie; Regesta I; Kloosterhuis 2006, 97; Sarnowsky 2001, 174175; Boockmann 1998, 108.

27 See Kloosterhuis 2006, 97-99; Sarnowsky 2001, 177-183 (a source of older literature).

28 Joachim 1896, iv-vi; Klein 1904; Klein 1905; Müller 2001; Kloosterhuis 2006, 112; E. 31. Marienburger Treßlerbuch. 
took place shortly before 25 December 1402, there is mention of the burning of a brickyard and a Hackelwerk, ${ }^{29}$ i.e., a quasi-suburbium, near the castle. During the attack 'certain Tatars', who had presumably been stationed in the Hackelwerk by the commander of Ragnit, were taken captive. ${ }^{30}$ The question arises: Where did these 'Tatars' come from and what ethnicity does the term actually represent? Analysis of the onomastic material in the Pomesanian judicial vicar's chronicle indicates that we are indeed dealing with people of Tatar origin. The ethnonym 'Tatars' was not used in this chronicle to describe various eastern peoples in general, as was quite common in the Latin cultural milieu of the 1230 s through the 1260 s, and continued to be prevalent in various Latin circles in the fourteenth and fifteenth centuries. ${ }^{31}$ At the turn of the fourteenth to the fifteenth century, this term was used by the Pomesanian author in relation to various Tatar-Turkish communities ${ }^{32}$ living in the Pontic-Caspian steppe

29 Regarding the etymology and meaning of the term, see Mittelhochdeutsches Wörterbuch III, 589a Zurkalowski 1906, 21 and n. 2; in reference to Hackelwerk in Ragnit, see Weber 1878, 541; Clasen-Sandt 1931, 200; Mortensen and Mortensen 1938, 109-110.

30 Posilge, 263:

Item korczlich vor wynachten qwomen die Littowin und Samaythin vor Rangnith das hus und vorbrantin die czygelschune und das hachelwerk, und trebin weg gefangen etliche Tatern, die der kompthur do gesatzt hatte, und ouch die ochsin

[Item shortly before Christmas Lithuanians and Samogitians appeared in Ragnit, in front of the castle, and burned the brick barn and the Hackelwerk, and abducted some Tatars previously settled there by the commander, as well as the oxen]

See also Weber 1878, 541; Mortensen and Mortensen 1938, 110. Regarding the LithuanianSamogitian attack on Ragnit, see Clasen-Sandt 1931, 206.

31 Bezzola 1974, 31, 41, 43-53, 57-65, 82-89, 100-109, 201-209; Connell 1973; Klopprogge 1993, 153-180, 214-216, 222-234; Schmieder 1994, 22-23, 66-72, 122-128, 201-247, 323-326; Grabski 1994, 34-53; Strzelczyk 2004a, 101-103, 108; Strzelczyk 2003, 230-231; Strzelczyk 1993, 60; Jackson 2005, 59, 136-147; Fried 1986, 318-320; von den Brincken 1975, 117-138; Tyszkiewicz 1989, 82. Regarding a much smaller number of genuine records about Mongols/Tatars and the problems they faced gaining acceptance among the elites of the period, see Jackson 2005, 329357; Klopprogge 1993, 222-223, 243-247; Schmieder 1994, 55-66; Fried 1986, 321-332; Strzelczyk 2004b, 241; Strzelczyk 2004a, 107-109 (these works include additional literature of the subject). 32 Posilge, 114-115 (the Battle of Kulikovo, 8 September 1380); 283 (Tatars supporting Grand Duke of Moscow Vasily I Dmitriyevich in 1406); 291 (Tatars supporting Grand Duke of Moscow Vasily I Dmitriyevich in 1407); 307 (Tatars supporting Grand Duke of Lithuania Alexander Vytautas in 1409); 314 (Tatars in Alexander Vytautas' army in 1410); 317 (Tatars at the Battle of Grunwald, 15 July 1410); 320 (Tatars in the grand duke's army near Marienburg in 1410); 340 (Tatars with Vlachs in Alexander Vytautas' army in 1414); 345 (Tatars in Prussia in 1414); 348 (Tatars encamped in Mazovia in 1414); 364 and 366 (internal Tatar struggles in 1416); 369 (Polish King Władysław II’s negotiations with the Tatars in 1416/1417); 382 (Tatars in Alexander Vytautas' army in 1419). 
(Desht-i Qipchaq) between the northern shores of the Black Sea in the west and the region of the Aral Sea in the east. ${ }^{33}$ The communities formed in this vast area as part of the new cultural system created by the Mongolian elite (including members of the Tatar and Mongol tribes) during the second half of the thirteenth century through the fourteenth century were quite ethnically diverse. The origins of these communities included the Turkish Cumans/Qipchaqs (Kipchaks), the Mongolian Tatars, the Caucasian Alans, and the Nogais, who were of both Mongolian and Turkish extraction. ${ }^{34}$ In the fourteenth century, the communities were linked by three cultural factors: 1) elements of the elite Mongolian culture that arrived with the Mongolian clans in the mid-thirteenth century; 2) the Qipchaq Turkish language, and 3) the spread of Islam beginning in the mid-thirteenth century. ${ }^{35} \mathrm{As}$ a result of their cultural continuity, by the turn of the fourteenth to the fifteenth century the nomads of Desht-i Qipchaq were uniformly referred to as 'Tatars', with their language also resulting in them being called 'Qipchaqs'. ${ }^{36}$

The political, economic, and cultural centre of the communities that existed as part of the Mongolian Golden Horde's political system at the time - a system rife with internal conflict ${ }^{37}$ - was located between the lower Don River and the lower Volga River (with New Sarai/Sarai Berke [Kolobovka] as its primary seat), on the areas named 'Qipchaq'. ${ }^{38}$ So it may be called the 'Desht-i Qipchaq Cultural Circle', i.e., cultural milieu of the steppes of Qipchaq. ${ }^{39}$ In this light, Jürgen Sarnowsky's identification of the source-related Tataren with the Sinti and Romani ethnic groups appears to be incorrect. ${ }^{40}$ The Romani people in particular did not begin to arrive in Central Europe from southern parts of this continent until the late fourteenth century and early fifteenth century. ${ }^{41}$

33 Egorov 1985, 27-47; Weiers 1989, 86; Weiers 1986, 347; Grekov and Yakubovskiy 1953, 5962, 64-66.

34 Williams 2001 10-14; Vásáry 2005, 71-72; Grekov and Yakubovskiy 1953, 240-241.

35 Kramarowsky 2002, 12, 14, 15-17; Grekov and Yakubovskiy 1953, 134-145 (the first work includes extensive literature on the subject).

36 Menges 1995, 60; Csáki 2006, 8-9; Tyszkiewicz 2008e, 43-44.

37 Grekov and Yakubovskiy 1953, 213-295; Grekov 1975, 207-217; Weiers 1986, 363-369; Kramarowsky 2002, 16-18; Jackson 2005, 216-219; Tyszkiewicz 1989, 113, 116.

38 Grekov and Yakubovskiy 1953, 20, 66, 71, 120-128, 141-145; Weiers 1986, 348; Kramarowsky 2002, 18.

39 Kramarowsky 2002, 17-18, 36-37.

40 Sarnowsky 2006/2008, 180-181 (no evidence is provided to support the thesis).

41 Fraser 2001, 53-55; 56-57, 94-95; Mróz 2001, 19, 25-33, 42-43, 68; Simoniukštyė 2002, 91. 
Sarnowsky only took into consideration the Tatern working on the Teutonic Order's farms in the early fifteenth century, not those from the Ragnit Castle. However, this particular identification of the ethnonym under discussion does not provide an explanation of how or why these alleged Romani people appeared in the Teutonic Order's courts and on its farms rendering service to the corporation. How did the Teutonic Brothers force the nomadic Romani people to adopt a sedentary lifestyle on convent farms as agricultural labourers and shepherds?

If we consider the way in which the Tatern most likely came to be in the vicinity of the Ragnit Castle, then the thesis that they were actual Tatars (in the broad sense of the word: Tatar-Turkish) appears more plausible. The descent of a group of people from one of the eastern steppe ethnic groups into Prussia at the turn of fourteenth to the fifteenth century could only have occurred in one of two ways. They were either prisoners taken in Lithuania during one of the Teutonic Order's expeditions against the Lithuanians, or they were prisoners directly abducted from the Eurasian steppe region. ${ }^{42}$

The latter option must be considered, given the participation of Teutonic Order contingents as auxiliaries in Lithuanian Grand Duke Alexander Vytautas' expeditions in 1398 and 1399 against Temür Qutlugh, Khan of the Golden Horde. ${ }^{43}$ While the second expedition ended in military defeat at the Battle of the Vorskla River on 12 August 1399, making it unlikely that Tatar prisoners were taken during that expedition, ${ }^{44}$ the 1398 expedition was successful and resulted in the construction of St. John's Castle (Johannisburg, Sente Johannesburg) at the mouth of the Dnieper River by the grand duke's army. ${ }^{45}$ It is probable that a small contingent of Tatar prisoners were brought back from this expedition.

42 Nikžentaitis 1997, 520; Nikžentaitis 1999, 200.

43 Posilge, 222, 229-231; FTAP, 229-230; Summarium, 226; Sarnowsky 1994, 258; Boockmann 1975, 74-75. In 1398, the Teutonic Order's military unit of sixty armoured men was commanded by the grand master's official (Kompan) Eberhard von Wallenfels. It is possible that some prisoners of war were taken by Marquard von Salzbach during the third Qipchaq expedition during the summer of 1399. Prussian records indicate that part of the grand duke's army, including the Teutonic contingent, survived the Battle of the Vorksla River. Regarding the Lithuanian expedition to the Black Sea, see Rowell 2008, 67-83; Rowell 2007, 185-194; Ivinskis 1978, 315317; Jackson 2005, 218-219; Heinl 1925, 166-167, 175-178.

44 Regarding the Battle of the Vorksla River, see Prochaska 2008 78-80; Kolankowski 1930, 70-72; Heinl 1925, 176-178; Pfitzner 1930, 149; Jackson 2005, 218-219; Tyszkiewicz 1989 124; Grekov 1985, 230-232; Prawdin 2009, 471-473; Ivinskis 1978, 316-318; Kiaupienè 2009, 356; Rowell 2008, 67-83.

45 Posilge, 222; Tyszkiewicz 2008e, 44-45; Ivinskis 1978, 315. 
The first alternative - Tatar prisoners abducted from Lithuania - would mean that the Tatern had been brought to the Ragnit Castle in 1402, because that was the only year in which the Teutonic Order was involved in military action in Lithuania during the period between 1397 and 1402.46 However, one should not exclude earlier explanations of this settlement related to the Teutonic Order's expedition to Lithuania in $1394 .{ }^{47}$ During the expedition in summer of 1402, which arrived in the area of Aukštaitija close to Vilnius, ${ }^{48}$ the Teutonic Order's troops could only have captured Tatar people who had either been brought to Lithuania during Grand Duke Alexander Vytautas' Black Sea expeditions in 1397 and 1398 or who had emigrated during an earlier period.49 Regardless of when the Tatars actually arrived, we are dealing with a population originating in the Eurasian steppe region.

The literature connects the resettlement of the population from the Black Sea area to Aukštaitija by the grand duke to the question of the Karaites/Karaims - the Qipchaq Jewish population. ${ }^{50}$ However, in the light of current research, it does not seem likely that the term Tatern in the Prussian sources would encompass those practising Rabbinic or Karaite Judaism.

Regardless of exactly when and how a group of Tatars appeared in the Ragnit Hackelwerk, it is beyond doubt that they had established a presence there by the end of 1402. The presence of a group of Tatars in the vicinity of

46 Paravicini 1995, Tab. 48, no. 38, p. 18; Tab. 49, nos. 282, 283, 283, p. 40; Ivinskis 1978, 330. 47 Paravicini 1995, Tab. 49, no. 259, p. 34; Prochaska 2008, 83-84; Kolankowski 1930, 62-63. 48 Posilge, 258-259 and n. 46.

49 Tyszkiewicz 1989, 117; Tyszkiewicz 2008e, 44; Šiaučiūnaitè-Verbickienė 2002b, 73-74; Sobczak 1984, 19-22. The emigration of Tatar Murzas and Beks, of either Mongolian or Qipchaq origin, began when internal struggle broke out in the Golden Horde following the death of the Khan Berdibek in 1358; it became more intense after 1395, when the Khan Tokhtamysh was defeated at a battle with Tamerlane and his leaders, forcing him to turn to Lithuania for support in 1396, see Tyszkiewicz 1989, 123; Sobczak 1984, 19. It was not only the warriors from the Horde who looked to Lithuania for aid, but the inhabitants of the towns situated along the Volga and the Don Rivers that had been destroyed by Tamerlane's army, see Grekov and Yakubovskiy 1953, 288-294; Tyszkiewicz 1989, 123; Jackson 2005, 216, 240; Quirini-Popławska 2002, 139. In 1362, approximately forty Mongolian warriors were taken prisoners of war at the Battle of Blue Waters and transferred to the Voke River in Lithuania, see Tyszkiewicz 2008e, 46-47.

50 Tyszkiewicz 2012, 20-23; Tyszkiewicz 1989, 148-150, 154-155, 159-160; Šiaučiūnaitè-Verbickienė 2002a, 83; Baliulis, Mikulionis, and Miškinis 1991, 21, 45-47; and particularly Gąsiorowski 2008, 165-168, 170-176 (including extensive literature of the subject matter). 
the Ragnit Castle was confirmed in Teutonic Order administrative documents from $1408^{51}$ and 1411.52

At the same time, this Ragnitan group was not the only Tatar population living in Prussia in the early fifteenth century. Tatars were also present beginning in 1402 on some farms in Lower (Niederland) and Upper Prussia (Oberland). The Marienburger Tresslerbuch records concerned farms in the following areas: Neuhof (Nowy Dwór Elbląski) in the Kammeramt (administrative region) of Fischau, between 1403 and 1408;53 Biester/Beister (no longer in existence) in the Kammeramt of Natangia, between 1402 and 1409; 54 Schaaken (Nekrasovo) in the Vogtei (administrative unit) of Samland (Sambia), between 1402 and $1408 ; 55$ in (Preußisch) Eylau (Bagrationovsk) in the Kammeramt of (Preußisch) Eylau, in 1409;56 and Memel (Klaipėda). 57

51 MTB 487.39-40 (Mai 1408): “Item $1 / 2$ m. den Tatern zu Ragnith [Item 0.5 mark for Tatars in Ragnit]".

52 GStA PK, Findmittel, Fb. 28, fol. 49 ; Heinrich-Mortensen 1927, 36, which confirms the presence of at least 12 Tatars in 1411, who had suffered losses during the military actions of 14091411.

53 MTB 245.22 (April 1403): "Item 2 scot den Tatthern zum Nuwenhove gegeben [Item 2 scots given to Tatars in Neuhof]"; MTB 481.40-41 (May 1408): "Item 2 scot den Tatern zum Nuwenhofe [as above]"; MTB 513.9-10 (30. 11. 1408): "Zum irsten 2 scot den Tatern im Nuwenhofe [First, 2 scots to Tatars in Neuhof]".

54 MTB 180.24-25 (August 1402): "und 4 scot den Tattern zum Byster [and 4 scots given to Tatars in Biester]"; MTB 236.30 (October 1403; Sarnowsky 2006/2008, 181, n. 27): "Item 4 schilling den Tathern zum Byster [Item 4 shillings given Tatars in Biester]"; MTB 252.36 (June 1403): "Item 1 scot den Tatern zum Bister gegeben [Item 1 scot given to Tatars in Biester]"; MTB 487.2 (May 1408): "Item 6 schilling den Tatern zu Bystern. [...] Item 7 schilling den selben Tatern, als [sie] unsern homeyster mit pyczen ereten [Item 6 shillings to Tatars in Biester ... Item 7 shillings to the same Tatars when (they) honoured our grand master with quirts]"; MTB 543.10-12 (May 1409), together with Lithuanian slaves; Sarnowsky 2006/2008, 181, n. 27: “Item 5 scot den Thatern und Littauwen. [...] Item 4 scot den Tatern, als sy unsern homeyster und groskompthur mit pytczen ereten [Item 5 scots to Tatars and Lithuanians ... Item 4 scots to the Tatars, when they honoured our grand master and grand commander with quirts]"; see Guttzeit 1977, 158-159; and Boockmann 1983, 555-579, 564 and n. 37; Boockmann 1991, 220. Regarding landed estates in the Commandery of Balga, see Boockmann 1983, 571; Guttzeit 1977, 156-161, 169-176.

55 MTB 181.11 (August 1402, a Tatar woman): "Item 1 firdung der Tatterkynne zu Schoken [Item 1 farden to a Tatar woman in Schaaken]"; MTB 487.32-33 (May 1408, unidentified Tatars): "Item 10 scot den Tatern zu Schoken [Item 10 scots to Tatars in Schaaken]"; MTB 490.5-6 (June 1408, unidentified Tatar servant): "Item $1 \mathrm{~m} 4$ scot eyme Tatern von Schoken gegeben $\mathrm{zu}$ Tapiaw vor syn lon [Item 1 mark 4 scots to a Tatar from Schaaken, given as a wage in Tapiau]". Mortensen and Mortensen 1938, 110, n. 466.

56 MTB 550.18-19 (July 1409): "Item 4 scot eyme Tatern mit syme wybe und 3 kindern [Item 4 scots given to a Tatar accompanied by his wife and three children]".

57 MTB 487.33-34 (Mai 1408): "Item 1 firdung den tatern zur Memel vor 3 sebe [Item 1 farden given to Tatars in Memel for three nets]". 
The Marienburger Tresslerbuch records are not the only administrative source of information about Tatars in Prussia. There is also a note preserved from the turn of the fourteenth to the fifteenth century regarding thirty-four captured Tatars, whom bailiffs (in German Kämmerer - local tax officials) were to distribute to courtyards in the Kammeramt of Waldau and the Kammeramt of Kremitten, in the Commandery of Königsberg. ${ }^{58}$ Based on geographic information, it seems likely that these were Tatars captured by the forces of the Commandery of Königsberg, indicating that contingents from this area were involved in one of the aforementioned Lithuanian military expeditions. Of all the expeditions against Lithuania between 1397 and 1404, the great expedition in the summer of 1402 seems most likely, 59 along with a smaller one in January 1403.60 During the first - as mentioned - the troops of the Teutonic Order arrived at the (New) Trakai, one of the grand duke's residences, ${ }^{61}$ around which 1397 and/or 1398 groups of captive Tatar warriors and Karaite/Karaim merchants had been placed. ${ }^{62}$ The second expedition arrived in the area of Hrodna (Grodno), where the captured Tatars had lived too. ${ }^{63}$ There are notes found in the 1409 Marienburger Tresslerbuch addressing the same issue. They concern the courtyard of the Kämmerer of Eylau, and indicate quite clearly that at least some of the captured Tatars were brought to Prussia, along with their wives and children. ${ }^{64}$

Taking into account the records preserved in the letters from 1408-1413, it is also possible that Tatar warriors were captured and brought to Prussia during smaller military actions carried out against Lithuanian military outposts in the Prussian-Lithuanian-Samogitian transition zone by individual Teutonic

58 GStA PK, OF 1a, fol. 292": "Dese gefangen furen dy kemerer Waldaw Caymen und Cremyten xxxiiij tatern [These prisoners were brought by Kämmerer: Waldau, Kaymen, and Kremitten: 34 Tatars]".

59 For these expeditions see references in n. 46.

60 Posilge, 264-265; Paravicini 1995, Tab. 49, no. 285, p. 40; Tab. 50, no. 36 , p. 44.

61 Baliulis, Mikulionis, and Miškinis 1991, 12-34; Petrauskas 2009, 379.

62 Tyszkiewicz 1989, 154-155, 157, 158, 159-161; Tyszkiewicz 2008e, 45; Tyszkiewicz 2012, 20

23; Baliulis, Mikulionis, and Miškinis 1991, 37.

63 Tyszkiewicz 1989, 161; Tyszkiewicz 2008e, 45.

64 MTB 550.18-19 (in the spring of 1409, an unidentified Tatar with a wife and three children); Boockmann 1983, 564 and n. 37. 
Order houses, given that these were manned by Tatars. ${ }^{65}$ This also might have been the case at the Prussian-Mazovian border. ${ }^{66}$

\subsection{The geographical distribution of the settlement sites}

In analysing the presence of Tatars in Prussia, the breadth of the geographical area they were spread across becomes clear. The seven sites verified by the

65 GStA PK, OBA 1025 (25 December [1408]), the record concerning the Tatars sent to Samogitia by Grand Duke Alexander Vytautas in order to gather information about conditions in the country:

das is im lande czu Samaithen richtig und wol steet, sunder das lant ist vol Rewszen, Tathern und Littawen und czien das lant dy twer und dy lenghe durch, und leghen obir den lewthen, alzo das sy clagen, das sy nicht mogen eynen hufen hews vor yn behalden

[that in the country of Samogitia everything is going well, but the whole country is crowded with Ruthenians, Tatars, and Lithuanians, who traverse the length and breadth of the country and stay with the people, so that they complain that they cannot hide even a haycock from them]

OBA 1772 (July-August 1412), a record concerning the manning of two castles erected by the Grand Duke Alexander Vytautas in Veliuona by Lithuanians, Poles, Ruthenians, and Tatars:

herczog Witowt czwey starke husze uff Welune gemacht hat und volbrocht, und hat die bemannet mit iiij ${ }^{\mathrm{C}}$ gewopenten mancherhande sprache als Littauwsch, Polnisch, Rusin und Tatarisch und manigvil

[Grand Duke Vytautas established two strong castles in Veliuona and completed them well, and allocated there 400 armed men of different languages: Lithuanian, Polish, $\mathrm{Ru}$ thenian, Tatar, and many (others)].

66 GStA PK, OBA 1163 [13] October [1413], information about Tatars with 200 horses encamped near Kluczbork, who were attacked by the commander of Osterode's troops:

sprengeten am freitage frue in dy Mosaw vor Crutzburg, und dy selbege nacht do logen dy Tatarn in der stadt mit $\mathrm{ij}^{\mathrm{C}}$ pferden und worden dez morgens frue gewarnet und sy randten ous, und vor randten uns den thamme alzo, daz wir uns lange mit inschossen und wir konden weder obendig dez thammes noch neder ubir komen, alzo daz wir ein erbarn knechte ouf deme thamme vorloren und faste der unsern gewondet syn, und der Tatern ouch vile gesthossen worden, wend ire hawffe yo longer ye grosse begende tzu werden

[(the commander of Osterode's people) appeared on Friday morning in Mazovia at Kluczbork, the same night Tatars with 200 horses camped in the town and were warned early in the morning and they leaped out of the town and met us on the dyke, so that for 
historical sources - Neuhof, Biester, (Preußisch) Eylau, Kremitten (no longer in existence), Waldau (Nizove), Schaaken, and Ragnit - spanned about 120 km, in four commanderies: Elbing (Elbląg), Balga, Königsberg (Kaliningrad), and Ragnit. Given that the Marienburger Tresslerbuch records only included information about places visited by great masters as they travelled the country, the possibility that Tatar prisoners were placed at additional sites after 1398 or 1402 cannot be excluded. Also the previously discussed note from 1402 or 1403 includes other sites assigned to specific groups of prisoners: Kaymen (Zarechye), Schaaken, Rudau (Melnikovo), and Wargen (Kotelnikovo) - all of which are the seats of Kämmerer in the Vogtei of Samland. ${ }^{67}$ As has been mentioned, records in the Marienburger Tresslerbuch attest to the presence of Tatars in Schaaken in 1402 and 1408.68 The list includes a total of forty additional people. It is impossible, however, in these cases, to determine whether Tatars or prisoners of a different ethnic origin are being discussed.

\subsection{Numbers}

Apart from the previously mentioned notes from 1402 or 1403 and 1411, there are no quantitative estimates regarding Tatar settlement in Prussia. The note regarding the thirty-four Tatars sent back to two Kämmerer courtyards ${ }^{69}$ suggests that these prisoners were settled in groups of a dozen or so. As a result, it is reasonable to presume there were about one hundred people coming from the Desht-i Qipchaq cultural milieu at the eight verifiable sites. It is difficult to determine whether the thirty-four people mentioned encompass all of the prisoners, or perhaps only the adults, or even only the men. If the latter were the case, given that we know entire families ${ }^{70}$ were taken captive, the Tatar population on Teutonic Order farms would have been considerably higher than suggested. Adding the forty persons mentioned in relation to four other Käm-

a long time we remained under their fire, and we were unable to pass either below or above the dyke, so that we lost one noble squire on the dyke, and many of us were wounded, and many Tatars were killed, as their horde grew over time].

67 GStA PK, OF 1a, fol. 292v: "Dese gefangen furen dy kemerer: Waldaw Caymen und Cremyten xxxiiij tatern, Caymen sunderlich x gefangen. Schaken x. Rudaw vij, item ij. Wargen viij, item iij [These prisoners were brought by the Kämmerer: Waldau, Kaymen, and Kremitten: 34 Tatars, moreover Kaymen 10 prisoners, Schaaken 10, Rudau 7, item 2. Wargen 8, item 3]”.

68 For the sources, see n. 55.

69 For the sources see n. 56.

70 For the sources, see n. 61 . 
merer courtyards in Samland would, of course, make the number even larger. As well, the number of Tatars in the vicinity of the Ragnit Castle might well have been greater than a dozen, given that twelve Tatars were recorded as injured in military actions around $1411 .{ }^{71}$ The total number of Tatars inhabiting the Prussian Land at the sites verified in the historical sources from the first decade of the fifteenth century ranged from fifty to 250 males and females. In the absence of further specific source material or archaeological data, an educated guess is the best that can be hoped for.

\subsection{Forms of settlement and their durability}

Both the Tatars settled on farms and those placed in Ragnit Hackelwerk were prisoners. Evidence for this is provided by the previously mentioned chronicle of a Pomesanian judicial vicar and by the presence of these people on the Order's working farms themselves. For people from Lithuania and from Deshti Qipchaq could not be found there as other than prisoners. It is difficult to believe that small groups of people of a foreign cultural background would voluntarily render unpaid service or even work for hire for the Teutonic Order's corporation. ${ }^{72}$

Given that no accounting records for all of Prussia after 1409 have been preserved, it is impossible for historians to trace Tatar settlement in Prussia beyond that point. One random note attached to a letter written by the commander of Ragnit on 15 June 1427 suggests the possibility of Tatars being sent from Lithuania to Prussia, but it does not confirm it. ${ }^{73}$ The available information indicates that Grand Duke Alexander Vytautas sent a few Tatars to the grand master, presumably as serfs. This note provides no information about the degree of stability of Tatar settlement near the Ragnit Castle from the beginning of the second decade to the end of the third decade of the fifteenth cen-

71 The sources, see n. 51.

72 Regarding the slave population, see my recent remarks, Kwiatkowski 2013, 425-430.

73 GStA PK, OBA 4776, fol. $2^{\text {r }}$ :

Ouch der herr homeister hot uns gebeten umbe sechs Thatteregen, die wir im ouch itczunt nicht fugglich kunden senden, sunder is das wir im die Thatter senden, so wellen wir denne euwer ouch nicht vorgessen

[In addition, the lord grand master requested (from Grand Duke Alexander Vytautas) 6 Tatar women, whom we could not send him earlier, and should we send him the Tatars, we will not forget about sending some of them to you (the Ragnitan commander) as well]. 
tury. It is impossible to determine whether or not this is also the case for the previously mentioned farms, with the possible exception of Schaaken, for which source records exist.

Two ambiguous grant documents were issued in Schaaken on 18 October and 13 December 1497 by grand commander Wilhelm Graf von Isenburg. These letters verify the existence of the 'Tatter's Farm' (Tatters Hof), covering an area of seven hides (Hufen) in the Kammeramt of Schaaken, which was given to Niclas and Peter von Sassen, along with other estates in the Kammeramt. ${ }^{74}$ Nearby were the estates of an unknown Jacob Tatter, who was probably a relative of another Jokub Thatar, a landowner in Samland in the Kammeramt of Schaaken in 1436, ${ }^{75}$ and of Hans Tatter, a landowner in the Kammeramt mentioned in the 1448 acts, ${ }^{76}$ who himself may well have been related to a cathedral canon in Dorpat, Johann Tatter (de Tataren, Tarteren, Tataren), mentioned in sources from the 1420s and 1430s. ${ }^{77}$ Is this a case of descendants of a Tatar family, who possibly settled with their fellows in Schaaken or nearby in 1402 or 1403? In the case of the family from Samland, it is not clear, whereas in the case of the Dorpat canon, it is out of question, as preserved sources from the end of the fourteenth century and the first half of the fifteenth century confirm close relations of other members of the Tatter family with Westphalia, the Rhineland, and Lübeck. ${ }^{78}$ The proper name itself, bearing as it does the fea-

74 GStA PK, Perg.-Urk., Schiebl. XXXIV, no. 112 (a landed estate in Sproden [Sprittlauken, Gorohov] of 7 hides and 4 additional hides is included here in a description provided by Jacob Tatter; this estate is also located in the Kammeramt of Schaaken); Perg.-Urk., Schiebl. 95, no. 62. The editors of the 'Pergamenturkunden' group's register suggest it was connected with Catharinenhoff (no longer in existence) near Grünhayn (Krasnaya Gorka) in Kammeramt of Tapiau, see Regesta II, no. 3752, p. 416; the issue requires further examination.

75 GStA PK, OBA 7266, fols. $1^{\mathrm{r}}-6^{\mathrm{r}}$, here fol. $1^{\mathrm{r}}$ (= edition: Mülverstedt 1885, $262=$ Vercamer 2010, Anhang. Quellen, no. 7, pp. 416-417, here 416).

76 GStA PK, OBA 9473, fols. $1^{\mathrm{r}}-6^{\mathrm{r}}$, here fol. $5^{\mathrm{v}}$ (= edition: ASP III 17, pp. 42-44, here $43=$ Vercamer 2010, Anhang. Quellen, no. 8, pp. 417-417, here 417; 19-20 Februar 1448); OBA 9564, Bl. 2 (= edition: ASP III 34, 20 June 1448); Mülverstedt 1855, 179 (note from p. 178).

77 GStA PK, OBA 5467 (= edition: LECUB 1/VIII 317 = BGP IV/1 164); OBA 5490 (= edition: LECUB 1/VIII 331 = BGP IV/1 176); OBA 5509 (= edition: LECUB 1/VIII 340 = BGP IV/1 182); OBA 5514 (= edition: LECUB 1/VIII 362 = BGP IV/1 193); OBA 5578 (= edition: LECUB 1/VIII 404 = BGP IV/1 203); LECUB 1/VIII 392 (= BGP IV/1 204); OBA 5654 (= edition: LECUB 1/VIII 465 = BGP IV/1 240); OBA 5733 (= edition: LECUB 1/VIII 493); OBA 5890 (= edition: BGP IV/1 320); OBA 6808 (= edition: BGP IV/2 611); OBA 6831 (= edition: BGP IV/2 615). About the canon, see Arbusow 1901, 120-121; Arbusow 1911-1913, 210-211; cf. RG 4/2, 2432-2434; RG 5/1, no. 5818. I would like to thank my colleague Radosław Krajniak (MA) for introducing the source publication to me.

78 Arbusow 1911-1913, 210 (Lodovicus Tatter); RG 2/1, 1046 (Sifridus Tacher [Thater]); RG 4, 3742 and RG 5, 9318 (Wilhemus Volperti de Tataren). The source confirms the purchase of wool 
tures of an ethnonym, is nonetheless suggestive. If the Tatters of Samland were actual descendants of the Tatars, which cannot be excluded, this would suggest a process of acculturation and assimilation. This is an issue that requires further detailed prosopographic research, as well as additional investigation of settlement records.

Sources from the first decade of fifteenth century concerning the courtyard in Schaaken, and the work of one of the Tatars there, indicate that, at least in some cases, it was possible for prisoners with families to see their captivity transformed over time into ongoing service to the Teutonic Order as servants (Knechte). ${ }^{79}$ The routine of their lifestyle encouraged adaptation to local conditions and acculturation, reducing the likelihood that they would attempt to escape from the Prussian Land. This acculturation may well have proceeded quite rapidly. It can also be assumed that the change in the living situation of Tatar prisoners was also encouraged by religious realities, as Christianization was undoubtedly an important factor in their integration into the Prussian cultural community.

The continuing presence and actual acculturation of the Tatar population in Prussia in the first half of the fifteenth century is confirmed by the record of resolutions presented at the convention of Prussian towns (Tagfahrt) in Elbing on 15 January 1441 . One of the questions discussed at the convention was the issue of admitting people who were not of noble origin (uneddele lewthe), including Tatars and Samogitians, into the newly founded Prussian Confederation (Preußischer Bund). The record provides evidence that in some instances this had, in fact, already occurred before convention took place. The decision taken at the convention changed that practice and expelled some members from the Prussian Confederation. ${ }^{80}$ The admission of Tatars to the Prussian

in England by a merchant named Werner Tatere from Lübeck, see HUB III, 406 (Nachtrag zu n. $735 \mathrm{im} \mathrm{Bd.} \mathrm{I);} \mathrm{the} \mathrm{source} \mathrm{confirms} \mathrm{that} \mathrm{a} \mathrm{Johannes} \mathrm{Tatere} \mathrm{was} \mathrm{a} \mathrm{town} \mathrm{councillor} \mathrm{in} \mathrm{Lübeck}$ in 1289, see LübUB II, no. 1090, p. 1032; LübUB I, 536 (8 July 1289); and a town councillor in 1290, see LübUB I 550 (16 May 1290); LübUB II 552 (25 June 1290); and a town councillor in 1292, see LübUB II 595 (15 August 1292); and a town councillor in 1295, see LübUB I 634 (20 June 1295); and a town councillor from 1289 to 1296, see LübUB I 656; sources from 1292 confirm that a merchant named Konrad Tatere travelled from Novgorod and Pskov; he was probably from Lübeck, see LECUB 1/VI 2770, Sp. 61 (= HUB II 187; and HUB III, 424 [Nachtrag zu n. $187 \mathrm{im} \mathrm{Bd}$. II]). Sources from 1427 confirm the existence of a merchant Hans van der Tateren in Hamburg, see HUB VI 672 (2 May 1427).

79 Regarding Knechte, see Kwiatkowski 2013, 406-416.

80 ASP II 190, pp. 295-299, here 298 (according to the Gdańsk manuscript):

Item alse denn die hersschafft vorgab, das wir uneddele lewthe alse kretczmer und derglichen in unser eynunge genomen hetten, und nach nemen, ist also gelassen, das men keynen uneddelen man, noch Thattern noch Samayten, kretczmer, gebawer adir schul- 
Confederation clearly indicates that at least some of them had been Christianized, because only Christians were admitted for the Confederation, and an oath (undoubtedly taken as a personal act before God and on the Holy Scripture) constituted an essential element for the entire Confederation (confederatio). ${ }^{81}$

czen, derleye lewthe in unser eynunge und vorschribung nemen will noch sall, sunder dy itczunt in unser eynunge gekomen synt, dy sullen dorinne bleiben, awsgenome schulczen, kretczmer, gebuwer unde sulche personen, alse itczundt czuvor berurt ist.

[Item as the authorities indicated that we have accepted and still accept in our union some ignoble people, such as innkeepers and those equal to them, it was established that no ignoble person, neither Tatars nor Samogitians, nor innkeepers, nor peasants nor village mayors shall be accepted in our union, however those who had already been incorporated into our union should remain in it, excluding village mayors, innkeepers, peasants, and those earlier stated.]

81 Janosz-Biskupowa and Biskup 1958, 125-137, Koncept I, § 7, pp. 129-130; Koncept II, § 7, pp. 134-135; ASP II 108, pp. 171-176, here 175-176; ASP II 107, pp. 167-170, here 169:

Wir burgermeister und ratmanne der stat N. bekennen und czugen offembar [...], das wir [...] mit eyntrechtigem gutten willen unser allir scheppen, burger, inwoner und ganczen gemeyne geloben und vorheyszen sulche eynung und vorschreibung, als dy strengen festen erbern und ersamen hern, ritter, knechte und stete diss landes uff dem tage Judica czu Marienwerder underenander geeynet, geslossen, vorschreben und bezegelt haben, in allen puncten und artikeln, alse dieselbe vorschreibung innehelt vor uns, unser scheppen, burger, inwoner und gancze gemeyne, dy nw und ouch czukumfftig sint, stete, feste und unvorsert in gutten rechtfertigem globen, bey truwen und eren czu halden, dobey czu bleiben, der czu gebruchen und noch gancz unser macht gnug czu thuende sunder eyngerley argelist in allen czukomenden czeiten

[We mayor and councillors of the town N. openly proclaim and certify (...), that we (...) with the unanimous good will of all our jurymen, citizens, inhabitants, and the entire community plight and promise, as to the union and regulation, which the brave, stable, venerable and honest lords, knights, squires, and towns of this country concluded among themselves, wrote down and sealed on the day of Judica in Marienwerder (Kwidzyn), in all points and articles that this regulation includes, in our name and the name of our jurymen, citizens, residents, and the entire community, those who are now and those who will be in the future, to constantly, firmly and inviolably in good, justified credence, faithfully and reverently to observe, abide by, and apply with all our might without any deceit in all future times]

See Janosz-Biskupowa and Biskup 1958, 126; moreover Biskup 1959, 40-41; Biskup 1975, 218 (using Marxist methodology, the scholar advances a hypothesis about the class nature of the Confederation; however, he contradicts himself, stating that the Confederation was a body that represented the country's population [Biskup 1975, 219]. Nevertheless, the record quoted here suggests that the Prussian Confederation was neither of a class or an ethnic nature: Originally, it was diversified, which to some extent reflects the political-social character of the heterogeneous system in the Prussian Land). 


\subsection{The possible role played by Tatars in the Prussian political and social system}

The above-mentioned sources do not provide the information necessary to determine what role Tatar prisoners played in Prussia. It should be assumed, however, that they were initially an unpaid workforce on the Teutonic Order's farms in Neuhof, Biester, (Preußisch) Eylau, Schaaken, Memel, Waldau, and Ragnit, where there were stud-farms or stockyards, although the earliest sources confirm that some of these only date from between the second and the fourth decades of the fifteenth century. ${ }^{82}$ Therefore, one must agree with Hartmut Boockmann, who points to the importance of Tatar prisoners in horse breeding. ${ }^{83}$ Their skill in breeding eastern horses, especially the Baltic sweiks (Sweiken) so important for the Teutonic Order's military, ${ }^{84}$ is beyond debate. ${ }^{85}$ It is difficult to establish exactly what role the Tatars in Waldau's stockyard and in Kremitten played, as there is no reliable information about the Teutonic Order's economic activity in these areas. ${ }^{86}$ It is possible that the Ragnit Hackel-

82 Neuhof (not confirmed until 1440): GÄB 99.37, 100.14 (8 May 1440); Biester: GÄB 151.25 (29 September 1383); 151.35-35, 152.1 (26 May 1387); 152.13 (12 March 1392); 157.8, 158.25-36, 161.20 (11 November 1412); 171.8-20 (4 July 1441); (Preußisch) Eylau: GÄB 151.33-34, 152.3 (26 May 1387); 152.10 (12 March 1393); 156.29-37 (11 November 1412); Schaaken: GÄB 15.38 (9 January 1414); 17.24 (1415); 19.36-37 (10 January 1422); 23. 9-13 (15 March 1422); 25.3-7 (18 November 1422); 27.34 (25 October 1424); Memel (stockyard [Viehhof] probably near the castle, perhaps later part of the town Althof), see Sembritzki 1918, 8 (only provides information about the functioning of the stockyard in 1402); Zurkalowski 1906, 19; Semrau 1929, 93, 95: GÄB 299.25 (13 July 1376); 300.11 (13 July 1377); 300.29 (1 January 1379); 301.8 (1389); 306.11 (2 January 1415); 306.21-22 (2 September 1416); MTB 137.3 ([24] July 1402; Sembritzki 1918, 8); Waldau: GÄB 27.28-29 (25 October 1424); 30.35-37 (11 July 1431); 33.21-23 (6 April 1434); 36.1-3 (17 October 1436); 41.39-40 (3 March 1438); 44.5-7 (1 March 1440); Ragnit: GÄB 258.11 (1379); 259.7 (4 December 1379); 261.4-5 (19 November 1392); 262.24 (1 May 1396); 264.34-35 (14 May 1402); 267.4-5 (1 September 1407); 278.2-4 (20 January 1419); 282.5-6 (4 October 1425); 286.3-4 (19 November 1432); Verwaltung 1968.

83 Boockmann 1983, 564, n. 37; 568, n. 57. The practice of installing Qipchaq prisoners of war and free warriors on landed estates, as well as those situated near castles, was not a practice exclusive to the Lithuanian grand duke's entourage; it was also the practice of Duke of Warsaw and Czersk Janusz I the Elder, see Tyszkiewicz 2001, 197; Tyszkiewicz 2008d, 57 (this includes the most important of older literature that primarily addresses the Tatar settlement in Lithuania).

84 Ekdahl 1991, 32; Ekdahl 1998, 123-124, 126-127; regarding Sweiken, see Chęć 2005, 360-361; Rünger 1925, 219, 225-227, 230-233; Töppen 1867, 686-687, 697-699; Bujack 1863, 313 (the last two do not recognize the military importance of indigenous horses).

85 Kwiatkowski 2013, 430.

86 Verwaltung 1968. 
werk was a Tatar military settlement, given that the settlements around commandery castles primarily fulfilled military functions. ${ }^{87}$ Furthermore, being a professional fighter does not in any way rule out horse breeding. On the contrary, one activity could, in this case, go hand in hand with the other.

\subsection{The question of acculturation}

The absence of any evidence of Tatar settlement in the areas under consideration during the second half of the fifteenth century (apart from the name of one of the courtyards in the Kammeramt of Schaaken at the end of the fifteenth century) might indicate a certain degree of successful acculturation. Virtually all of the factors that determined the existence of Tatar groups in Prussia would have favoured such a process: their small number, their dispersion over a large geographical area, separation from families and relatives, limited personal freedom, the lack of opportunity to participate in their native culture or practise their religion. ${ }^{88}$ Apart from that, in some rare cases, living in small biological families separated from a wider native community and left free to adopt a lifestyle suitable to their new conditions could have meant that people quickly adapted to the existent cultural patterns in their new place of residence. ${ }^{89}$ The acculturation of Tatars in late medieval Prussia was most likely a rapid and thorough process. This thesis is reinforced by the lack of any residual traces of Tatar culture in the local oral traditions or folk culture of the areas in which they settled in the former Prussia in the early fifteenth century.

\subsection{Conclusion}

To summarize, the following points are particularly important:

1. Tatar Muslims were not only present in Prussia for short periods of time as warriors supporting the armies of the Polish kings and the Lithuanian

87 Kwiatkowski 2013, 437-441, 444-445.

88 Regarding the social phenomenon of acculturation and of its complete form, assimilation, see Esser 2010, 9-10; Peuckert and Scher 2010, 203-204.

89 For an analysis of the cultural assimilation of the Tatar population in the Grand Duchy of Lithuania, see Zakrzewski 1989, 75-96; Borawski and Sienkiewicz 1989, 87-113; Borawski 1991a, 163-190; Borawski 1991b, 48-49. The latter researcher considers the geographical dispersion of families, clans, and groups to be the main reason for the acculturation of Tatars in the Grand Duchy of Lithuania. In the Prussian Land, the situation may well have been similar. 
grand dukes during expeditions in the fourteenth, fifteenth, and early sixteenth centuries. There was also a Tatar presence unrelated to war and confrontation.

2. Administrative and narrative sources from the Teutonic Order confirm the presence of Tatars from the steppes of the Black Sea and the Volga River (Desht-i Qipchaq) in Prussia at the beginning of the fifteenth century. The records undoubtedly concern Tatars, and not Romani or Sinti, as was suggested in earlier research.

3. Tatars were prisoners of war captured either in the steppes of the Black Sea by the Teutonic Order's contingent supporting Grand Duke Alexander Vytautas' army in 1398 or in Aukštaitija (possibly in the area of Trakai) during a Teutonic Order expedition to Lithuania (most likely in 1403).

4. It is possible that Tatars were taken as prisoners of war during other military actions carried out by the Teutonic Order's army in Lithuania and Samogitia at the turn of the fourteenth to the fifteenth century.

5. Tatars taken prisoner of war between 1398 and 1403 were, for the most part, settled on the Teutonic Order's farms and stud-farms in Memel, Ragnit, Neuhof, Biester, Schaaken, (Preußisch) Eylau, as well as in the Kammeramt of Waldau and the Kammeramt of Kremitten. It is also possible that some Tatar groups were settled in Kaymen, Rudau, and Wargen.

6. In the case of Ragnit, Tatar settlement might have been determined by military factors, while at other sites prisoners of war were exploited as workers on farms and stud-farms.

7. The number of individual Tatar groups inhabiting the Prussian Land at the beginning of the fifteenth century cannot be established with certainty: It would have encompassed fifty to 250 males and females.

8. It is possible that both individual warriors and entire Tatar families were deported to Prussia.

9. The sources generally only confirm the presence of a Tatar population in the Prussian Land during the first decade of the fifteenth century. It is only in the case of Ragnit that the sources also address the second decade of the fifteenth century. There are also general source records that confirm the presence of Tatars at the beginning of the fifth decade of the fifteenth century (1441). There are, however, no sources that confirm their presence in subsequent decades.

10. The 1441 record demonstrates the extensive acculturation of Tatars and their integration into the Christian community in the Prussian Land. This is further confirmed by other sources from both the fifth and the tenth decades of the fifteenth century.

11. The main factor in the acculturation of the Tatars from Desht-i Qipchaq was their limited numbers and their dispersion over a large geographical 
area. Given that there are no later residual traces of Tatar settlements in Prussia, fifteenth-century acculturation must have amounted to complete assimilation.

12. The relatively small number of Tatars inhabiting the Prussian Land at the beginning of the fifteenth century constituted a new factor in the multiethnic nature of settlement in Prussia - a country which, at that time, had all the features of a borderland area. It appears that the multi-ethnic nature of Prussia in the Late Middle Ages was much more complex than has been reflected in the literature addressing the issue up until this point.

13. It is important to stress that given their rapid social, religious, and linguistic acculturation, the Tatars from Desht-i Qipchaq cannot be regarded as a factor contributing to the alleged multi-cultural nature of the Prussian Land. Although Prussia in the Late Middle Ages remained a multi-ethnic country, the period from the thirteenth century to the early sixteenth century initially evinced the features of a bi-cultural (Latin Christian and Baltic pagan) socio-political structure, slowly evolving over time in the direction of cultural unification.

\section{Bibliography}

\section{Primary Sources}

ASP II = Acten der Ständetage Preussens unter der Herrschaft des Deutschen Ordens. Vol. 2.

Die Jahre 1436-1446. Ed. Max Töppen. Leipzig: Duncker \& Humblot, 1880.

ASP III = Acten der Ständetage Preussens unter der Herrschaft des Deutschen Ordens. Vol. 3.

Januar 1447 bis Juli 1453. Ed. Max Töppen. Leipzig: Duncker \& Humblot, 1882.

BGP IV/1 = Die Berichte der Generalprokuratoren des Deutschen Ordens an der Kurie. Bd. IV

(1429-1436). Tlbd. 1 (1429-1432). Eds. Kurt Forstreuter and Hans Koeppen. Göttingen:

Vandenhoeck \& Ruprecht, 1972.

BGP IV/2 = Die Berichte der Generalprokuratoren des Deutschen Ordens an der Kurie. Bd. IV

(1429-1436). Tlbd. 2 (1433-1436). Eds. Kurt Forstreuter and Hans Koeppen. Göttingen:

Vandenhoeck \& Ruprecht, 1976.

ChTP $=$ Chronica terrae Prussie 1029-1450. Ed. Ernst Strehlke. SRP III. 468-471.

Detmar = Abschnitte aus der Chronik Detmars von Lübeck. Ed. Ernst Strehlke. SRP III. 57-

237.

FTAP = Franciscani Torunensis Annales Prussici (941-1410). Ed. Ernst. Strehlke. SRP III. 57-

388.

GÄB = Das grosse Ämterbuch des Deutschen Ordens. Ed. Walther Ziesemer. Danzig: A. W.

Kafemann, 1921 [Wiesbaden: Sändig, 1968].

GStA PK, XX. HA Hist. StA Königsberg, Altfindmittel, Fotokopie = Geheimes Staatsarchiv

Preußischer Kulturbesitz, Berlin-Dahlem, XX. Hauptabteilung Historisches Staatsarchiv 
Königsberg, Altfindmittel, Fotokopie der originalen Handschrift von Erich Joachim, Regesta Historico-Diplomatica Ordinis S. Mariae Theutonicorum 1198-1525. Index Tabularii Ordinis S. Mariae Theutonicorum. Regesten zum Ordensbriefarchiv. Vols. 1-18. HUB II = Hansisches Urkundenbuch. Vol. 2. Ed. Verein für Hansische Geschichte. Halle: Verlag der Buchhandlung des Waisenhauses, 1879.

HUB III = Hansisches Urkundenbuch. Vol. 3. Nachträge und Erläuterungen zum ersten bis dritten Bande. Ed. Konstantin Höhlbaum. Halle: Verlag der Buchhandlung des Waisenhauses, 1882-1886. 377-487.

HUB VI - Hansisches Urkundenbuch. Vol. 6. 1415 bis 1433. Ed. Karl Kunze. Leipzig: Duncker \& Humblot, 1905.

LECUB 1/VI = Liv-, est- und kurländisches Urkundenbuch. Abt. 1. Vol. 6. Nachträge zu Band 1-5. Ed. Friedrich G. v. Bunge. Riga: Verlag von Nikolai Kymmel, 1873 [Aalen: ScientiaVerlag, 1974].

LECUB 1/ VIII = Liv-, est- und kurländisches Urkundenbuch. Abt. 1. Vol. 8. 1429 Mai - 1435. Ed. Hermann Hildebrand. Riga: Verlag von J. Deubner, 1884 [Aalen: Scientia-Verlag, 1974].

LübUB I = Codex diplomaticus Lubecensis / Lübeckisches Urkundenbuch. $1^{\text {ste }}$ Abth. Urkundenbuch der Stadt Lübeck. Teil 1. Ed. Verein für Lübeckische Geschichte und Alterthumskunde. Lübeck: Friedrich Aschenfeldt, 1843.

LübUB II = Codex diplomaticus Lubecensis / Lübeckisches Urkundenbuch. $1^{\text {ste }}$ Abth. Urkundenbuch der Stadt Lübeck. Teil 2. 2. Hälfte. Ed. Verein für Lübeckische Geschichte und Alterthumskunde. Lübeck: Friedrich Aschenfeldt, 1858.

MTB = Das Marienburger Tresslerbuch der Jahre 1399-1409. Ed. Erich Joachim. Königsberg i. Pr.: Thomas \& Oppermann, 1896 [Bremerhaven: Kniess, 1973].

$\mathrm{OBA}=\mathrm{GStA} P \mathrm{PK}, \mathrm{XX}$. HA Hist. StA Königsberg, Ordensbriefarchiv. $\mathrm{OF}=\mathrm{GStA} P K, \mathrm{XX}$. HA Hist. StA Königsberg, Ordensfolianten.

Perg.-Urk. = GStA PK, XX. HA Hist. StA Königsberg, Pergamenturkunden.

Posilge $=$ Johanns von Posilge, Officials von Pomesanien Chronik des Landes Preussen (von 1360 an, fortgesetzt bis 1419). Ed. Ernst Strehlke. SRP III. 79-388.

Regesta I = Regesta historico-diplomatica Ordinis S. Mariae Theutonicorum 1198-1525. Pars I: Index Tabularii Ordinis S. Mariae Theutonicorum / Regesten zum Ordensbriefarchiv. Eds. Erich Joachim and Walther Hubatsch. 3 vols. Göttingen: Vandenhoeck \& Ruprecht, 1948-1973.

Regesta II = Regesta historico-diplomatica Ordinis S. Mariae Theutonicorum 1198-1525. Pars II: Regesta Privilegiorum Ordinis S. Mariae Theutonicorum / Regesten der PergamentUrkunden aus der Zeit des Deutschen Ordens. Ed. Erich Joachim and Walther Hubatsch. Göttingen: Vandenhoeck \& Ruprecht, 1948.

RG 2/1 = Repertorium Germanicum. Regesten aus den päpstlichen Archiven zur Geschichte des Deutschen Reichs und seiner Territorien im XIV. und XV. Jahrhundert. Vol. 2. Urban VI., Bonifaz IX., Innocenz VII. und Gregor XII. (1378-1415). Lfg. 1: Einleitung und Regesten. Ed. Gerd Tellenbach. Berlin: Weidmannsche Verlagsbuchhandlung, 1933-1938 [Hildesheim: Georg Olms Verlag/Weidmannsche Verlagsbuchhandlung, 2000].

RG 4/2 = Repertorium Germanicum. Regesten aus den päpstlichen Archiven zur Geschichte des Deutschen Reichs und seiner Territorien im XIV. und XV. Jahrhundert. Vol. 4. Martin V. (1417-1431). Tl. 2 (I, J, Y). Ed. Karl A. Fink. Berlin: Weidmann, 1957 [Hildesheim: Georg Olms Verlag/Weidmannsche Verlagsbuchhandlung, 2000].

RG 5/1 = Repertorium Germanicum. Regesten aus den päpstlichen Archiven zur Geschichte des Deutschen Reichs und seiner Territorien im XIV. und XV. Jahrhundert. Vol. 5. Eugen 
IV. (1431-1447). Tl. 1: Text. Ed. Hermann Diener, Brigide Schwarz, and Christoph

Schöner. Tübingen: Niemeyer, 2004.

$\mathrm{SRP}=$ Scriptores rerum Prussicarum. Die Geschichtsquellen der preussischen Vorzeit bis zum

Untergange der Ordensherrschaft. Eds. Theodor Hirsch, Max Töppen, and Ernst Strehlke.

5 vols. Leipzig: Hirzel, 1861-1874.

Summarium = Summarium von Jagel und Wytaut (Beilage Paul Pole's Preussische Chronik).

Ed. Max Töppen. SRP V. Leipzig: Duncker \& Humblot, 1874. 223-227.

\section{Literature}

Arbusow, Leonid. "Livlands Geistlichkeit vom Ende des 12. bis ins 16. Jahrhundert (Fortsetzung)." Jahrbuch für Genealogie, Heraldik und Sphragistik 9 (1901): 1-160.

Arbusow, Leonid. "Livlands Geistlichkeit vom Ende des 12. bis ins 16. Jahrhundert (Dritter Nachtrag).” Jahrbuch für Genealogie, Heraldik und Sphragistik 16 (1911-1913): 1-432.

Baliulis, Algirdas, Stanislovas Mikulionis, and Algmimantas Miškinis. Trakų miestas ir pilys. Istorija ir architektūra. Vilnius: Mokslas, 1991.

Bezzola, Gian A. Die Mongolen in abendländischer Sicht (1220-1270). Ein Beitrag zur Frage der Völkerbegegnungen. Bern: Francke, 1974.

Biskup, Marian. Zjednoczenie Pomorza Wschodniego z Polska w połowie XV wieku. Warsaw: Państwowe Wydawnictwo Naukowe, 1959.

Biskup, Marian. "Der preußische Bund 1440-1454 - Genesis, Struktur, Tätigkeit und Bedeutung in der Geschichte Preußens und Polens." Hansische Studien III. Bürgertum Handelskapital - Städtebünde. Eds. Konrad Fritze, Eckhard Müller-Mertens, and Johannes Schildhauer. Weimar: Hermann Böhlaus Nachfolger, 1975. 210-229.

Biskup, Marian. Wojny Polski z Zakonem Krzyżackim (1308-1521). Gdańsk: Marpress, 1993.

Biskup, Marian. "Die Blüte des Deutschordensstaates in Preußen im 14. Jahrhundert." Die Geschichte des Deutschen Ordens in Preußen. Wirtschaft - Gesellschaft - Staat Ideologie. Eds. Marian Biskup and Gerard Labuda. Trans. Jürgen Heyde and Ulrich Kodur. Osnabrück: Fibre, 2000. 291-382.

Boockmann, Hartmut. Johannes Falkenberg, der Deutsche Orden und die polnische Politik. Göttingen: Vandenhoeck \& Ruprecht, 1975.

Boockmann, Hartmut. "Die Vorwerke des Deutschen Ordens in Preußen." Die Grundherrschaft im späten Mittelalter. Tl. 1. Ed. Hans Patze. Sigmaringen: Jan Thorbecke Verlag, 1983. 555-579.

Boockmann, Hartmut. "Spielleute und Gaukler in den Rechnungen des DeutschordensHochmeisters." Feste und Feiern im Mittelalter. Eds. Detlef Altenburg, Jörg Jarnut, and Hans-Hugo Steinhoff. Sigmaringen: Jan Thorbecke Verlag, 1991. 217-227.

Boockmann, Hartmut. Der Deutsche Orden. Zwölf Kapitel aus seiner Geschichte. $4^{\text {th }}$ edn. Munich: Verlag C. H. Beck, 1994.

Boockmann, Hartmut. Ostpreußen und Westpreußen. $3^{\text {rd }}$ edn. Berlin: Siedler Verlag, 1995.

Boockmann, Hartmut. "Die Briefe des Deutschordenshochmeisters." Kommunikationspraxis und Korrespondenzwesen im Mittelalter und in der Renaissance. Eds. Heinz-Dieter Heimann and Ivan Hlaváček. Paderborn: Ferdinand Schöningh, 1998. 103-112.

Borawski, Piotr. "Tatarzy-ziemianie w dobrach Radziwitłów (XVI-XVIII w.).” Przegląd Historyczny 82.1 (1991a): 33-49.

Borawski, Piotr. “Asymilacja kulturowa Tatarów w Wielkim Księstwie Litewskim.” Odrodzenie i Reformacja w Polsce 36 (1991b) [1992]: 163-190. 
Borawski, Piotr, and Witold Sienkiewicz. "Chrystianizacja Tatarów w Wielkim Księstwie Litewskim.” Odrodzenie i Reformacja w Polsce 34 (1989): 87-113.

Brincken, Anna-Dorothee von den. "Die Mongolen im Weltbild der Lateiner um die Mitte des 13. Jahrhunderts unter besonderer Berücksichtigung des 'Speculum historiale' des Vinzenz von Beauvois OP.” Archiv für Kulturgeschichte 57 (1975): 117-140.

Bujack von, Georg. "Die Pferdezucht in der Provinz Preußen.” Die Provinz Preussen: Geschichte ihrer Kultur und Beschreibung ihrer land- und forstwirthschaftlichen Verhältnisse. Festgabe für die Mitglieder der XXIV. Versammlung deutscher Land- und Forstwirthe, zu Königsberg in Pr. [No editor]. Königsberg: F. I. Dalkowski, 1863. 312-371.

Chęć, Adam. “Hodowla koni w komturii malborskiej.” Archaeologia Historica Polona 15.2 (2005: Przeszłość z perspektywy źródet materialnych i pisanych): 359-366.

Clasen-Sandt, Käthe. "Zur Baugeschichte der Memelburgen Ragnit, Splitter und Tilsit." Prussia. Zeitschrift für Heimatkunde und Heimatschutz 29 (1931): 196-222.

Connell, Charles W. "Western Views of the Origin of the 'Tartars': An Example of the Influence of Myth in the Second Half of the Thirteenth Century." Journal of Medieval and Renaissance Studies 3 (1973): 115-137.

Csáki, Éva. Middle Mongolian Loan Words in Volga Kipchak Languages. Wiesbaden: Harrassowitz Verlag, 2006.

Czaja, Roman. "Der Handel des Deutschen Ordens und der preußischen Städte - Wirtschaft zwischen Zusammenarbeit und Rivalität." Ritterorden und Region. Politische, soziale und wirtschaftliche Verbindungen im Mittelalter. Ed. Zenon H. Nowak. Toruń: Wydawnictwo Naukowe UMK, 1995a. 111-123.

Czaja, Roman. "Związki gospodarcze wielkich szafarzy zakonu krzyżackiego z miastami pruskimi na początku XV w.” Zakon Krzyżacki a społeczeństwo państwa w Prusach. Zbiór studiów. Ed. Zenon H. Nowak. Toruń: Towarzystwo Naukowe w Toruniu, 1995b. 9-34.

Czaja, Roman. Miasta pruskie a zakon krzyżacki. Studia nad stosunkami między miastem a władzą terytorialna w późnym średniowieczu. Toruń: Wydawnictwo Naukowe UMK, 1999.

Czaja, Roman. "Preußische Hansestädte und der Deutsche Orden. Ein Beitrag zu den Beziehungen zwischen Stadt- und Landesherrschaft im späten Mittelalter." Hansische Geschichtsblätter 118 (2000): 57-76.

Czarciński, Ireneusz. “Dzieje Chełmży do połowy XV wieku.” Dzieje Chełmży. Ed. Mieczysław Wojciechowski. Chełmża: Chełmżyńskie Towarzystwo Kultury, 1994. 25-46.

Długokęcki, Wiesław. "Kolonizacja ziemi chełmińskiej, Prus i Pomorza Gdańskiego do 1410 r.” Państwo zakonu krzyżackiego w Prusach. Władza i spoteczeństwo. Eds. Marian Biskup and Roman Czaja. Warsaw: Wydawnictwo Naukowe PWN, 2008a. 200-217.

Długokęcki, Wiesław. “Odbudowa osadnictwa, kolonizacja i przemiany wsi w państwie krzyżackim (1411-1525).” Państwo zakonu krzyżackiego w Prusach. Wtadza i spoteczeństwo. Eds. Marian Biskup and Roman Czaja. Warsaw: Wydawnictwo Naukowe PWN, 2008b. 375-383.

Egorov 1985 = Егоров, Вадим Л. Историческя география Золотой Орды в XIII-XIV вв. Москва: Наука, 1985.

Ekdahl, Sven. "Das Pferd und seine Rolle im Kriegswesen des Deutschen Ordens.” Das Kriegswesen der Ritterorden im Mittelalter. Ed. Zenon H. Nowak. Toruń: Wydawnictwo Naukowe UMK, 1991. 29-47.

Ekdahl, Sven. "Horses and Crossbows: Two Important Warfare Advantages of the Teutonic Order in Prussia." The Military Orders. Vol. 2: Welfare and Warfare. Ed. Helen Nicholson. Aldershot: Ashgate, 1998. 119-151. 
Esser, Hartmut. “Akkulturation.” Grundbegriffe der Soziologie. Eds. Johannes Kopp and Bernhard Schäfers. $10^{\text {th }}$ edn. Wiesbaden: VS Verlag für Sozialwissenschaften, 2010. 9-12.

Ewald, Albert L. Die Eroberung Preussens durch die Deutschen. 4 vols. Halle (Saale): Verlag der Buchhandlung des Waisenhauses, 1872-1886.

“E. 31. Marienburger Treßlerbuch." Unter Kreuz und Adler. Der Deutsche Orden im Mittelalter. Ausstellung des Geheimen Staatsarchivs Preußischer Kulturbesitz anläßlich des 800jähriges Bestehens des Deutschen Ordens. Ed. Friedrich Benninghoven. Berlin: Geheimes Staatsarchiv Preußischer Kulturbesitz, 1990. 108.

Forstreuter, Kurt. "Der Deutsche Orden und Südosteuropa." Kyrios. Vierteljahresschrift für Kirchen- und Geistesgeschichte Osteuropas 1.3 (1936): 245-272.

Fraser, Angus M. Dzieje Cyganów. Trans. Ewa Klekot. Warsaw: Państwowy Instytut Wydawniczy, 2001.

Fried, Johannes. "Auf der Suche nach der Wirklichkeit. Die Mongolen und die europäische Erfahrungswissenschaft im 13. Jahrhundert.” Historische Zeitschrift 243.2 (1986): 287332.

Gąsiorowski, Stefan. Karaimi w Koronie i na Litwie w XV-XVIII wieku. Kraków: Wydawnictwo Austeria, 2008.

Golden, Peter B. Nomads and their Neighbours in the Russian Steppe: Turks, Khazars and Qipchaqs. Aldershot: Ashgate, 2003.

Górski, Karol. Ustrój państwa i Zakonu Krzyżackiego. Gdynia: Instytut Battycki, 1938.

Górski, Karol. Państwo krzyżackie w Prusach. Gdańsk: Instytut Battycki, 1946.

Górski, Karol. L'Ordine teutonico. Alle origini dello stato prussiano. Trans. Salomon A. Vivanti. Turin: Einaudi, 1971.

Górski, Karol. "The Teutonic Order in Prussia." Communitas, Princeps, Corona Regni. Studia Selecta. Ed. Karol Górski. Warsaw: Państwowe Wydawnictwo Naukowe, 1976. 13-31.

Górski, Karol. Zakon krzyżacki a powstanie państwa pruskiego. Wrocław: Zakład Narodowy im. Ossolińskich, 1977.

Górski, Karol. “Ustrój państwa i zakonu krzyżackiego w Prusach.” Studia i szkice z dziejów państwa i zakonu krzyżackiego. Ed. Karol Górski. Olsztyn: Wydawnictwo Pojezierze, 1986. 21-102.

Grabski, Andrzej F. "Najazd tatarski 1241 r. w opiniach Europy Zachodniej. Myślenie ideologiczne a postrzeganie rzeczywistości." Bitwa legnicka. Historia i tradycja. Ed. Wactaw Korta. Wroctaw: Uniwersytet Wrocławski, 1994. 34-53.

Grekov 1975 = Греков, Игоръ Б. Восточная Европа и упадок Золотой Орды XIV-XV вв. Москва: Наука, 1975.

Grekov and Yakubovskiy 1953 = Grekow, Boris D., and Aleksandr Ju. Jakubowski. Ztota Orda i jej upadek. Trans. Władysław Głuchowski. Warsaw: Książka i Wiedza, 1953.

Guttzeit, Emil J. “Ordenshöfe im westlichen Natangen.” Natangen. Landschaft und Geschichte. Gesammelte Beiträge. Ed. Emil J. Guttzeit. Marburg (Lahn): J. G. HerderInstitut, 1977. 154-178.

Heinl, Karl. Fürst Witold von Litauen in seinem Verhältnis zum Deutschen Orden in Preussen während der Zeit seines Kampfes um sein litauisches Erbe: 1382-1401. Berlin: Verlag von Emil Ebering, 1925.

Heinrich-Mortensen, Gertrud. Beiträge zu den Nationalitäten- und Siedlungsverhältnissen von Pr.-Litauen. Berlin: Memelland-Verlag, 1927.

Hoffmann, Hanns H. "Die Krise des Deutschen Ordens." Die Welt zur Zeit des Konstanzer Konzils. Ed. Theodor Mayer. Sigmaringen: Jan Thorbecke Verlag, 1965. 63-81. 
Horváth, András P. Petschenegen, Kumanen, Jassen. Steppenvölker im mittelalterlichen Ungarn. Trans. János Thimar. Budapest: Corvina-Verlag, 1989.

Ivinskis, Zenonas. Rinktiniai raštai. Vol. 1. Iki Vytauto Didžiojo mirties. Rome: Lietuvių Katalikų Mokslo Akademija, 1978.

Jackson, Peter. The Mongols and the West, 1221-1410. Harlow: Pearson Education, 2005. Jähnig, Bernhart. "Litauische Einwanderung nach Preußen im 16. Jahrhundert. Ein Bericht zum dritten Band von Hans und Gertrud Mortensen.” Zur Siedlungs- und Bevölkerungsund Kirchengeschichte Preussens. Ed. Udo Arnold. Lüneburg: Institut Nordostdeutsches Kulturwerk, 1999. 75-94.

Janosz-Biskupowa, Irena, and Marian Biskup. "Ze studiów nad konceptem aktu erekcyjnego Związku Pruskiego z 14 III 1440 r.” Studia Źródtoznawcze 3 (1958): 125-137.

Jasiński, Tomasz. "Die westfälische Einwanderung in Preußen im Spätmittelalter." Zur Siedlungs- und Bevölkerungs- und Kirchengeschichte Preussens. Ed. Udo Arnold. Lüneburg: Institut Nordostdeutsches Kulturwerk, 1999. 95-110.

Jenks, Stuart. "Die Ordnung für die englische Handelskolonie in Danzig (23. Mai 1405).” Danzig in acht Jahrhunderten. Beiträge zur Geschichte eines hansischen und preußischen Mittelpunkt. Eds. Bernhart Jähnig and Peter Letkemann. Münster: NicolausCopernicus-Verlag, 1985. 105-120.

Joachim, Erich. "Vorwort." Das Marienburger Tresslerbuch der Jahre 1399-1409. Ed. Erich Joachim. Königsberg i. Pr.: Thomas \& Oppermann, 1896. iii-ix.

Joachim, Erich. "König Sigismund und der Deutsche Ritterorden in Ungarn, 1429-1432. Mitteilungen aus dem Staatsarchiv zu Königsberg.” Innsbruck: Wagner’sche k. k. Universitäts-Buchdruckerei, 1911.

Kloosterhuis, Jürgen. "Strukturen und Materien spätmittelalterlicher Amtsbücher im Spiegel von Ordensfolianten." Preussens erstes Provinzialarchiv. Zur Erinnerung an die Gründung des Staatsarchivs Königsberg vor 200 Jahren. Eds. Bernhart Jähnig and Jürgen Kloosterhuis. Marburg: N. G. Elwert Verlag, 2006. 85-121.

Kiaupienè, Jūratė. "Lietuvos Didžiosios Kunigaikštystės ir Lenkijos Karalystės dinastinis ryšys ir jo transformacijos." Lietuvos istorija. Vol. 4. Naujii horizontai: dinastija, visuomenè, valstybé. Lietuvos Didžioji Kunigaikštystė 1386-1529 m. Ed. Jūratė Kiaupienė and Rimvydas Petrauskas. Vilnius: Baltos Lankos, 2009. 352-367.

Klein. Albert. Die zentrale Finanzverwaltung im Deutschordensstaate Preußen am Anfang des 15. Jahrhunderts. Nach dem Marienburger Tresslerbuch. Leipzig: Duncker \& Humblot, 1904.

Klein, Albert. Entstehung und Komposition des Marienburger Tresslerbuches. Ein Beitrag zur Kritik mittelalterlicher Rechnungsbücher. Offenbach (Main): Forger, 1905.

Klopprogge, Axel. Ursprung und Ausprägung des abendländischen Mongolenbildes im 13. Jahrhundert. Ein Versuch zur Ideengeschichte des Mittelalters. Wiesbaden: Harrassowitz Verlag, 1993.

Kolankowski, Ludwik. Dzieje Wielkiego Księstwa Litewskiego za Jagiellonów. Vol. 1. 13771499. Warsaw: Skład Gtówny Kasa im. Mianowskiego, 1930.

Krakowski, Stefan. Polska w walce z najazdami tatarskimi w XIII wieku. Warsaw: Wydawnictwo Ministerstwa Obrony Narodowej, 1956.

Kramarowsky, Mark G. “Die Goldene Horde: 'Antwort aus der Zukunft'.” Die Schätze der Goldenen Horde aus der Eremitage in St. Petersburg. Ausstellungskatalog. Loeben: Stadtgemeinde, 2002. 10-44.

Kubon, Sebastian. “Konflikt oder Kooperation? Das Verhältnis des Deutschen Ordens zu seinen preußischen Hansestädten und Untertanen im Spiegel der auswärtigen 
Beziehungen zu England (1377-1422)." Vorstellungswelten der mittelalterlichen Überlieferung. Zeitgenössische Wahrnehmungen und ihre moderne Interpretation. Ed. Jürgen Sarnowsky. Göttingen: V \& R unipress, 2012. 91-118.

Kwiatkowski, Krzysztof. "Die militärische Funktion der Städte unter der Herrschaft des Deutschen Ordens in Preußen (vom 13. bis zum Anfang des 15. Jh.)." Städtelandschaften im Ostseeraum im Mittelalter und in der Frühen Neuzeit. Eds. Roman Czaja and Carsten Janke. Toruń: Wydawnictwo UMK, 2009a. 167-186.

Kwiatkowski, Krzysztof. “Okoliczności wypowiedzenia wojny królowi polskiemu Władysławowi II przez wielkiego mistrza zakonu niemieckiego Ulricha von Jungingen w sierpniu 1409 roku.” Zapiski Historyczne 74.3 (2009b): 7-33.

Kwiatkowski, Krzysztof. Zakon niemiecki jako 'corporatio militaris'. p. 1: Korporacja i krąg przynależących do niej: kulturowe i społeczne podstawy działalności militarnej zakonu w Prusach (do początku XV wieku). Toruń: Wydawnictwo UMK, 2013.

Labuda, Gerard. "Entstehung und Entwicklung des Deutschordensstaates in Preussen." Die Geschichte des Deutschen Ordens in Preußen. Wirtschaft - Gesellschaft - Staat Ideologie. Ed. Marian Biskup and Gerard Labuda. Trans. Jürgen Heyde and Ulrich Kodur. Osnabrück: Fibre, 2000. 115-290.

Łowmiański, Henryk. "Polityka ludnościowa Zakonu Niemieckiego w Prusach i na Pomorzu." Prusy - Litwa - Krzyżacy. Ed. Marceli Kosman. Warsaw: Państwowy Instytut Wydawniczy, 1989. 125-126.

Maercker, Hans. Geschichte der ländlichen Ortschaften und der drei kleineren Städte des Kreises Thorn. Danzig: Th. Bartling, 1899-1900.

Małtek, Janusz. “Migracje ludności niemieckiej, polskiej i litewskiej na ziemie pruskie w XIIIXVIII wieku.” Komunikaty Mazursko-Warmińskie 4 (242) (2003): 431-441.

Maschke, Erich. "Preußen. Das Werden eines deutschen Stammesnamens." Domus hospitalis Theutonicorum. Europäische Verbindungslinien der Deutschordensgeschichte. Gesammelte Aufsätze aus den Jahren 1931-1963. Ed. Udo Arnold. Bonn (Godesberg): Wissenschaftliches Archiv, 1970. 158-187.

Menges, Karl H. The Turkic Languages and Peoples. An Introduction to Turkic Studies. Wiesbaden: Harrassowitz Verlag, 1995.

Mentzel-Reuters, Arno. "Unde den vride machten wider in dem lande - Kriegsziele in der Historiographie des Deutschen Ordens." Ordines Militares Colloquia Torunensia Historica. Yearbook for the Study of the Military Orders 18 (2013): 93-96.

Militzer, Klaus. Die Geschichte des Deutschen Ordens. Stuttgart: W. Kohlhammer, 2005. Mittelhochdeutsches Wörterbuch. Mit Benutzung des Nachlasses v. Georg F. Benecke. Eds. Wilhelm Müller and Friedrich Zarncke. Vol. 3. Leipzig: Hirzel, 1866. < http:// www.woerterbuchnetz.de/ >

Mortensen, Hans. "Die litauische Wanderung." Nachrichten der Gesellschaft der Wissenschaften in Göttingen, Philologisch-Historische Klasse (1927): 177-195.

Mortensen, Hans. "Die litauische Einwanderung nach Ostpreußen.” Prussia. Zeitschrift für Heimatkunde und Heimatschutz 30.1 (1933): 133-141.

Mortensen, Hans, and Gertrud Mortensen. Die Besiedlung des nordöstlichen Ostpreussens bis zum Beginn des 17. Jahrhunderts. Tl. 1: Die preußisch-deutsche Siedlung am Westrand der Großen Wildnis um 1400. Leipzig: Hirzel, 1937.

Mortensen, Hans, and Gertrud Mortensen. Die Besiedlung des nordöstlichen Ostpreussens bis zum Beginn des 17. Jahrhunderts. Tl. 2: Die Wildnis im östlichen Preußen, ihr Zustand um 1400 und ihre frühere Besiedlung. Leipzig: Hirzel, 1938.

Mróz, Lech. Dzieje Cyganów-Romów w Rzeczypospolitej XV-XVIII w. Warsaw: DiG, 2001. 
Müller, Karsten. Das Marienburger Tresslerbuch als Beispiel mittelalterlicher Rechnungslegung. Hagen, 2001 [Studienarbeit].

Mülverstedt, Georg A. von. "Das älteste Vasallen-Register des Samlandes, sowie der Gebiete Insterburg und Gerdauen aus dem Jahre 1436." Neue Preußische Provinzial Blätter A.F. 7 (1855): 177-195, 256-291.

Nikžentaitis, Alvydas. "Belaisviai Lietuvoje ir Vokiečių ordino valstybèje (1283-1409)." Lietuvos valstybe XII-XVIII a. Vilnius: Lietuvos istorijos instituto l-kla, 1997. 507-526.

Nikžentaitis, Alvydas. "Prisoners of War in Lithuania and the Teutonic Order State (12831409)." Der Deutsche Orden in der Zeit der Kalmarer Union 1397-1521. Eds. Zenon H. Nowak and Roman Czaja. Toruń: Wydawnictwo UMK, 1999. 193-208.

Paravicini, Werner. Die Preussenreisen des europäischen Adels. Tl. Il. Sigmaringen: Jan Thorbecke Verlag, 1995.

Päsler, Ralf G. Deutschsprachige Sachliteratur im Preußenland bis 1500. Untersuchungen zu ihrer Überlieferung. Köln: Böhlau, 2003.

Penners, Theodor. Untersuchungen über die Herkunft der Stadtbewohner im DeutschOrdensland Preußen bis in die Zeit um 1400. Leipzig: Hirzel, 1942.

Petrauskas, Rimvydas. "Vytauto laikai. Suverenus valdovas." Lietuvos istorija. Vol. 4. Naujii horizontai: dinastija, visuomenè, valstybè. Lietuvos Didžioji Kunigaikštystė 1386-1529 m. Eds. Jūratė Kiaupienè and Rimvydas Petrauskas. Vilnius: Baltos Lankos, 2009. 368-387.

Peuckert, Rüdiger, and Albert Scher. "Minderheiten.” Grundbegriffe der Soziologie. Eds. Johannes Kopp and Bernhard Schäfers. $10^{\text {th }}$ edn. Wiesbaden: VS Verlag für Sozialwissenschaften, 2010. 203-206.

Pfitzner, Josef. Groszfürst Witold von Litauen als Staatsmann. Brunn: Rohrer, 1930.

Powierski, Jan. "Stosunki ludnościowe w państwie krzyżackim.” Dzieje Warmii i Mazur w zarysie. Vol. 1. Od pradziejów do 1870 roku. Eds. Jerzy Sikorski and Stanisław Szostakowski. Warsaw: Państwowe Wydawnictwo Naukowe, 1981. 134-141.

Prawdin, Michael. The Mongol Empire: Its Rise and Legacy. $4^{\text {th }}$ edn. New Jersey: Transaction Publishers, 2009.

Prochaska, Antoni. Dzieje Witolda wielkiego księcia Litwy. $2^{\text {nd }}$ edn. Kraków: Universitas, 2008.

Quirini-Popławska, Danuta. Włoski handel czarnomorskimi niewolnikami w późnym średniowieczu. Kraków: Universitas, 2002.

Rowell, Stephen C. “Naujieji kryžiaus žygiuotojai: LDK ir Bizantijos santykiai XIV-XV a. sandūroje. Ar Vytautas Didysis buvo Lietuvos kryžiaus žygių prieš turkus bei totorius pradininkas?" Kryžiaus karu epocha Baltijos regionu tautu istorinèje sąmonèje. Mokslinių straipsnių rinkinys. Eds. Rita R. Trimonienė and Robertas Jurgaitis. Saulès: Saulès delta, 2007. 181-204.

Rowell, Stephen C. "Ne wisai primintinos kautynès: ką byloja šaltiniai apie 1399 m. mųši ties Vorsklos upe?" Istorijos šaltinių tyrimai. Vol. 1. Eds. Darius Antanavičius and Darius Baronas. Vilnius: LII leidykla, 2008. 67-89.

Rünger, Fritz. "Herkunft, Rassezugehörigkeit, Züchtung und Haltung der Ritterpferde des Deutschen Ordens. Ein Beitrag zur Geschichte der ostpreußischen Pferdezucht und der deutschen Pferdezucht im Mittelalter." Zeitschrift für Tierzüchtung und Züchtungsbiologie einschließlich Tierernährung 2 (1925): 211-308.

Sarnowsky, Jürgen. "The Teutonic Order confronts Mongols and Turks." The Military Orders. Vol. 1. Fighting for the Faith and Caring for the Sick. Ed. Malcolm Barber. Aldershot: Ashgate, 1994. 253-262. 
Sarnowsky, Jürgen. “Identität und Selbstgefühl der geistlichen Ritterorden.” Ständische und religiöse Identitäten in Mittelalter und früher Neuzeit. Eds. Stefan Kwiatkowski and Janusz Mattek. Toruń: Wydawnictwo UMK, 1998. 109-130.

Sarnowsky, Jürgen. "Die Quellen zur Geschichte des Deutschen Ordens in Preußen.” Edition deutschsprachiger Quellen aus dem Ostseeraum (14.-16. Jahrhundert). Eds. Matthias Thumser, Janusz Tandecki, and Dieter Heckmann. Toruń: Wydawnictwo UMK, 2001. 171199.

Sarnowsky, Jürgen. Der Deutsche Orden. Munich: C. H. Beck, 2007.

Sarnowsky, Jürgen. "Preußen und Rhodos als multiethnische Gesellschaften des 15. Jahrhunderts." Beiträge zur Geschichte Westpreußens 20/21 (2006/2008): 175-187.

Schmieder, Felicitas. Europa und die Fremden. Die Mongolen im Urteil des Abendlandes vom 13. bis in das 15. Jahrhundert. Sigmaringen: Jan Thorbecke Verlag, 1994.

Schumacher, Bruno. Geschichte Ost- und Westpreußens. $6^{\text {th }}$ edn. Würzburg: Holzner Verlag, 1977.

Sembritzki, Johannes. Geschichte des Kreises Memel. Festgabe zum Andenken an die 34jährige Verwaltung des Kreises. Memel: F. W. Siebert, 1918.

Semrau, Arthur. "Beiträge zur Topographie der Burg und der Stadt Memel im Mittelalter." Mitteilungen des Coppernicus-Vereins für Wissenschaft und Kunst zu Thorn 37 (1929). 89-116.

Šiaučiūnaitè-Verbickienè, Jurgita. "The Karaims." The Peoples of the Grand Duchy of Lithuania. Ed. Grigorijus Potašenko. Vilnius: Aidai, 2002a. 83-89.

Šiaučiūnaitè-Verbickienè, Jurgita. "The Tatars." The Peoples of the Grand Duchy of Lithuania. Ed. Grigorijus Potašenko. Vilnius: Aidai, 2002b. 73-82.

Simoniukštyè, Aušra. "The Roma." The Peoples of the Grand Duchy of Lithuania. Ed. Grigorijus Potašenko. Vilnius: Aidai, 2002. 90-100.

Sobczak, Jacek. Położenie prawne ludności tatarskiej w Wielkim Księstwie Litewskim. Warsaw: Państwowe Wydawnictwo Naukowe, 1984.

Souhr, Annika. "Relacje zakonu krzyżackiego z Toruniem w czasie wypraw gotlandzkich na przetomie XIV/XV w.” Rocznik Toruński 36 (2009): 7-37.

Souhr, Annika. “'Von jeher fredeschild der Christenheit’. Rückgriffe auf die eigenen Ursprünge im Schriftverkehr des Deutschen Ordens in Krisenzeiten (15. Jahrhundert).” La mémoire des origines dans les ordres religieux-militaires au Moyen Âge: actes des journées d'études de Göttingen (25-26 juin 2009) / Die Erinnerung an die eigenen Ursprünge in den geistlichen Ritterorden im Mittelalter: Beiträge der Göttinger Tagung (25.-26. Juni 2009). Eds. Philippe Josserand and Mathieu Olivier. Berlin: Lit, 2012. 237268.

Strzelczyk, Jerzy. “Wstęp. Mongołowie a Europa. Stolica Apostolska wobec problemu mongolskiego do połowy XIII wieku." Spotkanie dwóch światów. Stolica Apostolska a świat mongolski w połowie XIII w. Relacje powstate w zwiazzu z misja Jana di Piano Carpiniego do Mongotów. Ed. Jerzy Strzelczyk. Poznań: “Abos”, 1993. 7-112.

Strzelczyk, Jerzy. "Oko w oko z wcieleniem Goga i Magoga. Jan di Piano Carpini w poselstwie do wielkiego chana." 'Klucz do poznania nieba'. Z dziejów myśli racjonalistycznej $w$ średniowieczu. Ed. Jerzy Strzelczyk. Gdańsk: Novus Orbis, 2003. 203-258.

Strzelczyk, Jerzy. “Granice wyobraźni na Wschodzie.” Średniowieczny obraz świata. Poznań: Wydawnictwo PTPN, 2004a. 85-112.

Strzelczyk, Jerzy. "Stolica Apostolska a świat mongolski w połowie XIII wieku." Średniowieczny obraz świata. Ed. Jerzy Strzelczyk. Poznań: Wydawnictwo PTPN, 2004b. 217-241. 
Thumser, Matthias. "Eine neue Aufgabe im Heidenkampf? Pläne mit dem Deutschen Orden als Vorposten gegen die Türken." Europa und die Türken in der Renaissance. Eds. Bodo Guthmüller and Wilhelm Kühlmann. Tübingen: Niemeyer, 2000. 139-176.

Töppen, Max. “Anmerkungen.” Petri de Dusburg Chronicon terre Prusie. Ed. Max Töppen. SRP I (1861). 21-219.

Töppen, Max. "Über die Pferdezucht in Preußen zur Zeit des deutschen Ordens, nebst einigen Bemerkungen über die Sweiken.” Altpreußische Monatschrift 4 (1867): 681-702.

Tyszkiewicz, Jan. "Rejestr chorągwi tatarskich walczących w wojnie polsko-krzyżackiej 15191521 roku." Zapiski Historyczne 53.1-2 (1988): 85-99.

Tyszkiewicz, Jan. Tatarzy na Litwie i w Polsce. Studia z dziejów XIII-XVIII w. Warsaw: Państwowe Wydawnictwo Naukowe, 1989.

Tyszkiewicz, Jan. Ostatnia wojna z Zakonem Krzyżackim 1519-1521. Warsaw: Państwowe Wydawnictwo Naukowe, 1991.

Tyszkiewicz, Jan. "Pod murami miasta i zamku. Tatarzy na późnośredniowiecznym Mazowszu." Rocznik Mazowiecki 13 (2001): 193-197.

Tyszkiewicz, Jan. “Chorągwie tatarskie w wojnie pruskiej: 1519-1521." Tatarzy w Polsce $i$ Europe. Fragmenty dziejów. Ed. Jan Tyszkiewicz. Puttusk: Akademia Humanistyczna im. Aleksandra Gieysztora, 2008a. 139-148.

Tyszkiewicz, Jan. "Dwa hufce tatarskie w bitwie pod Grunwaldem.” Tatarzy w Polsce i Europe. Fragmenty dziejów. Ed. Jan Tyszkiewicz. Pułtusk: Akademia Humanistyczna im. Aleksandra Gieysztora, 2008b. 71-87.

Tyszkiewicz, Jan. “Oddziały Tatarów litewskich w wojnie trzynastoletniej.” Tatarzy w Polsce $i$ Europe. Fragmenty dziejów. Ed. Jan Tyszkiewicz. Puttusk: Akademia Humanistyczna im. Aleksandra Gieysztora, 2008c. 111-124.

Tyszkiewicz, Jan. "Tatarzy z Litwy na dworach książąt mazowieckich: od końca XIV do początku XVI wieku.” Tatarzy w Polsce i Europe. Fragmenty dziejów. Ed. Jan Tyszkiewicz. Pultusk: Akademia Humanistyczna im. Aleksandra Gieysztora, 2008d. 49-58.

Tyszkiewicz, Jan. "Ze stepu Deszt-i-Kipczak do Kyrkłar." Tatarzy w Polsce i Europe. Fragmenty dziejów. Ed. Jan Tyszkiewicz. Puttusk: Akademia Humanistyczna im. Aleksandra Gieysztora, 2008e. 43-47.

Tyszkiewicz, Jan. “Dzieje Karaimów w państwie polsko-litewskim do końca XV wieku i ich związki z Krymem.” Karaimi. Ed. Beata Machul-Telus. Warsaw: Wydawnictwo Sejmowe, 2012. 11-24.

Vásáry, István. Cumans and Tatars. Oriental Military in the Pre-Ottoman Balkans, 1185-1365. Cambridge: Cambridge University Press, 2005.

Vercamer, Grischa. Siedlungs-, Sozial- und Verwaltungsgeschichte der Komturei Königsberg in Preußen (13.-16. Jahrhundert). Marburg: N. G. Elwert Verlag, 2010.

"Verwaltung des Ordenslandes Preußen um 1400." (map) Historisch-geographischer Atlas des Preußenlandes. Lieferung 1. Eds. Hans Mortensen, Gertrud Mortensen, and Reinhard Wenskus. Wiesbaden: Franz Steiner Verlag, 1968.

Weber, Lotar. Preussen vor 500 Jahren in culturhistorischer, statistischer und militärischer Beziehung nebst Special-Geographie. Danzig: In Commission bei Theodor Bertling, 1878.

Weiers, Michael. "Die Goldene Horde oder das Khanay Qyptschaq." Die Mongolen. Beiträge zu ihrer Geschichte und Kultur. Ed. Michael Weiers. Darmstadt: Wissenschaftliche Buchgesellschaft, 1986. 345-378.

Weiers, Michael. "Geschichte der Mongolen." Die Mongolen und ihr Weltreich. Ed. Arne Eggebrecht with Eva Eggebrecht and Manfred Gutgesell. Mainz/Rhein: von Zabern, 1989. 45-114. 
Weise, Erich. “Der Heidenkampf des Deutschen Ordens.” Zeitschrift für Ostforschung 12.3 (1963): 420-473; 13.3 (1964): 401-420.

Wenskus, Reinhard. "Das Ordensland Preussen als Territorialstaat des 14. Jahrhundert." Ausgewählte Aufsätze zum frühen und preußischen Mittelalter. Festgabe zu seinem 70. Geburtstag. Ed. Hans Patze. Sigmaringen: Jan Thorbecke Verlag, 1986a. 317-352.

Wenskus, Reinhard. "Der deutsche Orden und die nichtdeutsche Bevölkerung des Preußenlandes mit besonderer Berücksichtigung der Siedlung." Ausgewählte Aufsätze zum frühen und preußischen Mittelalter. Festgabe zu seinem 70. Geburtstag. Ed. Hans Patze. Sigmaringen: Jan Thorbecke Verlag, 1986b. 353-374.

Wenskus, Reinhard. "Kleinverbände und Kleinräume bei den Prussen des Samlandes." Ausgewählte Aufsätze zum frühen und preußischen Mittelalter. Festgabe zu seinem 70. Geburtstag. Ed. Hans Patze. Sigmaringen: Jan Thorbecke Verlag, 1986c. 245-298.

Wenta, Jarosław. “Kariera Jana z Dobrzynia?” Zapiski Historyczne 52.1 (1987). 169-174. Wenta, Jarosław. Kierunki rozwoju rocznikarstwa w państwie zakonu niemieckiego w Prusach. Toruń: Towarzystwo Naukowe w Toruniu, 1990.

Wenta, Jarosław. Studien über die Ordensgeschichtsschreibung am Beispiel Preußens. Toruń: Wydawnictwo UMK, 2000.

Williams, Brian G. The Crimean Tatars: The Diaspora Experience and the Forging of a Nation. Leiden: Brill, 2001.

Wyrozumski, Jerzy. Kazimierz Wielki. Wrocław: Zakład Narodowy im. Ossolińskich, 1982.

Zajączkowski, Stanisław. Podbój Prus i ich kolonizacja przez Krzyżaków. Toruń: Instytut Battycki, 1935.

Zakrzewski, Andrzej B. “O asymilacji Tatarów w Rzeczypospolitej w XVI-XVIII w.” Tryumfy $i$ porażki. Studia z dziejów kultury polskiej XVI-XVIII w. Ed. Maria Bogucka. Warsaw: Państwowe Wydawnictwo Naukowe, 1989. 75-96.

Żmudzki, Paweł. Studium podzielonego Królestwa - książę Leszek Czarny. Warsaw: Wydawnictwo Neriton, 2000.

Zurkalowski, Erich. "Studien zur Geschichte der Stadt Memel und der Politik des Deutschen Ordens.” Altpreußische Monatsschrift 43 (1906): 145-191 (= book edition: Königsberg i. Pr.: Buchdruckerei R. Leupold, 1906; citations from the book edition). 